\title{
Feeding habits variability of Lutjanus synagris and Lutjanus griseus in the littoral of Campeche, Mexico: an approach of food web trophic interactions between two snapper species
}

\author{
Paloma G. Juárez-Camargo ${ }^{1}$, Atahualpa Sosa-López ${ }^{2}$, Yassir Edén Torres-Rojas ${ }^{2}$ \\ Edgar Fernando Mendoza-Franco ${ }^{2} \&$ Sergio Aguiñiga García ${ }^{3}$ \\ ${ }^{1}$ Maestría Multidisciplinaria para el Manejo de la Zona Costero-Marina, Instituto de Ecología Pesquerías y \\ Oceanografía del Golfo de México (EPOMEX), Universidad Autónoma de Campeche \\ (EPOMEX-UAC), Campeche, México \\ ${ }^{2}$ Instituto de Ecología, Pesquerías y Oceanografía del Golfo de México (EPOMEX) \\ Universidad Autónoma de Campeche (EPOMEX-UAC), Campeche, México \\ ${ }^{3}$ Instituto Politécnico Nacional, Centro Interdisciplinario de Ciencias Marinas \\ La Paz, Baja California Sur, México \\ Corresponding author: Yassir Edén Torres-Rojas (yetorres@uacam.mx)
}

\begin{abstract}
The study of the feeding habits variability (spatial and temporal scales) allows us to evaluate the trophic interactions between species, thus, the short and long-term effects of the removal of different species by the presence of different phenomena. In this study, we carried out stable isotope $\left(\delta^{13} \mathrm{C}\right.$ and $\left.\delta^{15} \mathrm{~N}\right)$ and stomach content analyses to infer the trophic linkages between two snapper species (Lutjanus synagris and Lutjanus griseus) captured in the littoral of Campeche, Mexico. In total, 781 specimens were collected (528 L. synagris and 253 L. griseus) and based on relative importance index [\%PSIRI] both snapper species consumed based on the prey-specific index of relative importance (PSIRI), Penaeidae family (PSIRI $=23.41 \%$ ) was the most important species in the diet of Lutjanus synagris, while Callinectes sapidus (PSIRI $=21.45 \%$ ) was the primary prey of Lutjanus griseus. The isotopic analyses indicated that both snapper species feed in the coastal-marine $\left(\delta^{15} \mathrm{~N}\right.$ : 10.6 to $12.1 \%$ and $\delta^{13} \mathrm{C}$ : -15.7 to $-12.7 \%$ ); however, according to PERMANOVA, low diet similarity was found between snapper species $(\mathrm{R}=0.07, P<0.01)$, also, significant differences was detected in the $\delta^{15} \mathrm{~N}$ and $\delta^{13} \mathrm{C}$ values between $L$. synagris, and L. griseus. Therefore, despite both snapper species presents similar trophic positions (L. synagris: $4.2 \pm 0.2 ;$ L. griseus: $3.9 \pm 0.1$ ) and feeding behavior (according to SIBER = opportunistic predators), a low trophic overlap was observed, probably associated with the differential use of habitat in the coastal zone; where L. synagris is ecologically fed in areas of seagrass, while L. griseus is probably intermittent between pasture and mangrove areas, therefore, the role of each species is crucial in the dynamics of coastal-marine ecosystems as predators and potential structuring of the populations of their prey.
\end{abstract}

Keywords: Lutjanus synagris; L. griseus; stable isotope; small-scale fisheries; mixing model; coastal-marine; Gulf of Mexico

\section{INTRODUCTION}

The lutjanids fishes comprise 17 genera with 43 species of primarily reef-dwelling marine perciform fishes occurring in tropical and subtropical waters of the eastern Pacific, Indo-west Pacific, and eastern and western Atlantic oceans (Bester et al., 2015). The largest genus in the family, Lutjanus, has 68 valid species (Froese \& Pauly, 2010), of which two snapper species (Lutjanus synagris and L. griseus) are the most representative in the Gulf of Mexico with high commercial value due to their high market demand. In the Gulf of Mexico, snapper landings accounted for close to $26 \mathrm{t} \mathrm{yr}^{-1}$, with a commercial value of around USD 35,000 $\mathrm{yr}^{-1}$, highlighting the economic importance of these species (CONAPESCA, 2019).

The littoral of Campeche constitutes suitable habitat for L. synagris and L. griseus, reporting high catch rates. In recent years, commercial snapper landings in the Gulf of Mexico reached maximum levels of 35 to 
$40 \mathrm{t}$ between 2016 and 2017. In this sense, the volume of landings increased by over $46 \%$ in the last decade (CONAPESCA, 2019). Therefore, one research effort has focused on the study of biodiversity and feeding habits variability in the trophic networks (Pimm, 2002; De Ruiter et al., 2005). These studies on trophic interaction among species provide guidelines for identifying potential consequences of natural perturbations and management decisions on a coastal fishery system and the conservation of ecosystems.

The analyses of the feeding habits variability between two or more predators generate information to understand the interspecific relationships among different species in the community and the impact of the overexploitation of a resource or the presence of natural phenomena the ecosystems (Kareiva \& Levin, 2003). For example, in other regions, lutjanids fishes are reported as species that capture, store, and transfer energy in the food-web complexity (Garrido et al., 2008; Vaslet et al., 2012). The importance of the lutjanids in the food web lies in the high number of interactions than they maintain with their prey. Specific studies related a diet of lutjanids inhabiting in the Gulf of Mexico have evidenced that $L$. synagris and $L$. griseus are nocturnal generalist predators (RiveraArriaga, 1993; Sámano-Zapata et al., 1998; Guevara et al., 2007), with differences in their trophic interactions relate to the ontogenetic condition (Sierra, 1996; Guevara et al., 2007; Bester et al., 2015). However, few studies have been carried out on the feeding habits variability of $L$. synagris and $L$. griseus in the Yucatan Peninsula. Therefore, the interactions of both snapper species in their natural habitat and the potential ecological impacts by overfishing that may decrease populations of these fishes remain unknown.

The combined use of stomach contents and stable isotopes $\left(\delta^{15} \mathrm{~N}\right.$ and $\left.\delta^{13} \mathrm{C}\right)$ analyses have provided a taxonomic resolution of prey consumed by predators and habitat use, respectively (Maruyama et al., 2001; McIntyre \& Flecker, 2006). $\delta^{13} \mathrm{C}$ has been useful in providing information on autotrophic sources and $\delta^{15} \mathrm{~N}$ as an indicator of trophic position within a local or regional food web. Additionally, standard deviation evidence that the variety of food resources used by an organism over a long period (Post, 2002; Bearhop et al., 2004). Therefore, these techniques provide knowledge about niche width, trophic overlap, and trophic position at a spatial and temporal level.

The objective of the present study was to establish the feeding habits variability of $L$. synagris and $L$. griseus based on stomach contents and stable isotope $\left(\delta^{15} \mathrm{~N}\right.$ and $\left.\delta^{13} \mathrm{C}\right)$ analyses to describe possible variations among sex and fishing locations. This information could help describe the trophic interactions of two snapper species that are more relevant to ecosystem processes in the southern Gulf of Mexico for developing futures stages and adaptation options, which is considered key to the management of fisheries at the ecosystem level.

\section{MATERIALS AND METHODS}

\section{Sample collection}

Sampling was carried out at three different locations of Campeche, Mexico (Fig. 1). The first location is Champoton, which is characterized by sandy beaches and limos rich in organic matter product of the trawling of the nearby rivers; the second location in San Francisco de Campeche and is characterized by a transition of terrigenous materials and calcareous sediments; and the third location is Seybaplaya, which is characterized by rocky beaches and sands being a transition zone between Champoton and San Francisco de Campeche (Rivera-Arriaga et al., 2012).

In the three fishing locations, snapper species were sampled monthly during three climatic seasons in 2015 (12 months): dry (D) from February to May; rainy season (R) from June to September and wind/winter season (W) from October to January (Yáñez-Arancibia $\&$ Day, 1982). Samples were collected from the smallscale fishery (fishing boats were $7 \mathrm{~m}$ long with $75 \mathrm{hp}$ outboard motors), which operates year-round. The fishing maneuvers are carried out by two or more fishermen by boat, with two sets for four hours each at night. The fishing gear consists of $200 \mathrm{~m}$ long monofilament gillnets of nylon, 75 meshes deep, and $7.5-8.8 \mathrm{~cm}$ mesh size. Once snappers were identified, 30 individuals were collected in each fishing location (781 ind) and kept frozen $\left(-20^{\circ} \mathrm{C}\right)$ until analysis in the Trophic Ecology Laboratory at the Instituto de Ecología, Pesquerías y Oceanografía del Golfo de México (EPOMEX) in Campeche, Mexico.

In the laboratory, fork length (FL) in $\mathrm{cm}$ and weight (g) of each specimen were recorded. We collected stomachs and dorsal white muscle tissue $(5 \mathrm{~g})$ to obtain information on recently consumed food (stomach contents $=$ days) and assimilated food (white muscle tissue $=$ months). The muscle tissue of the main prey items and stomach contents analysis was also collected in the same area and time as the snapper samples.

For stomach content analyses, we determined the percentage of stomach-filling based on Stillwell \& Kohler (1982) and thawed the stomach contents and categorized the digestive state of the prey species according to the digestive levels described by GalvánMagaña (1988). The identification of fishes was based on descriptions given by Castro-Aguirre (1999), Fischer 


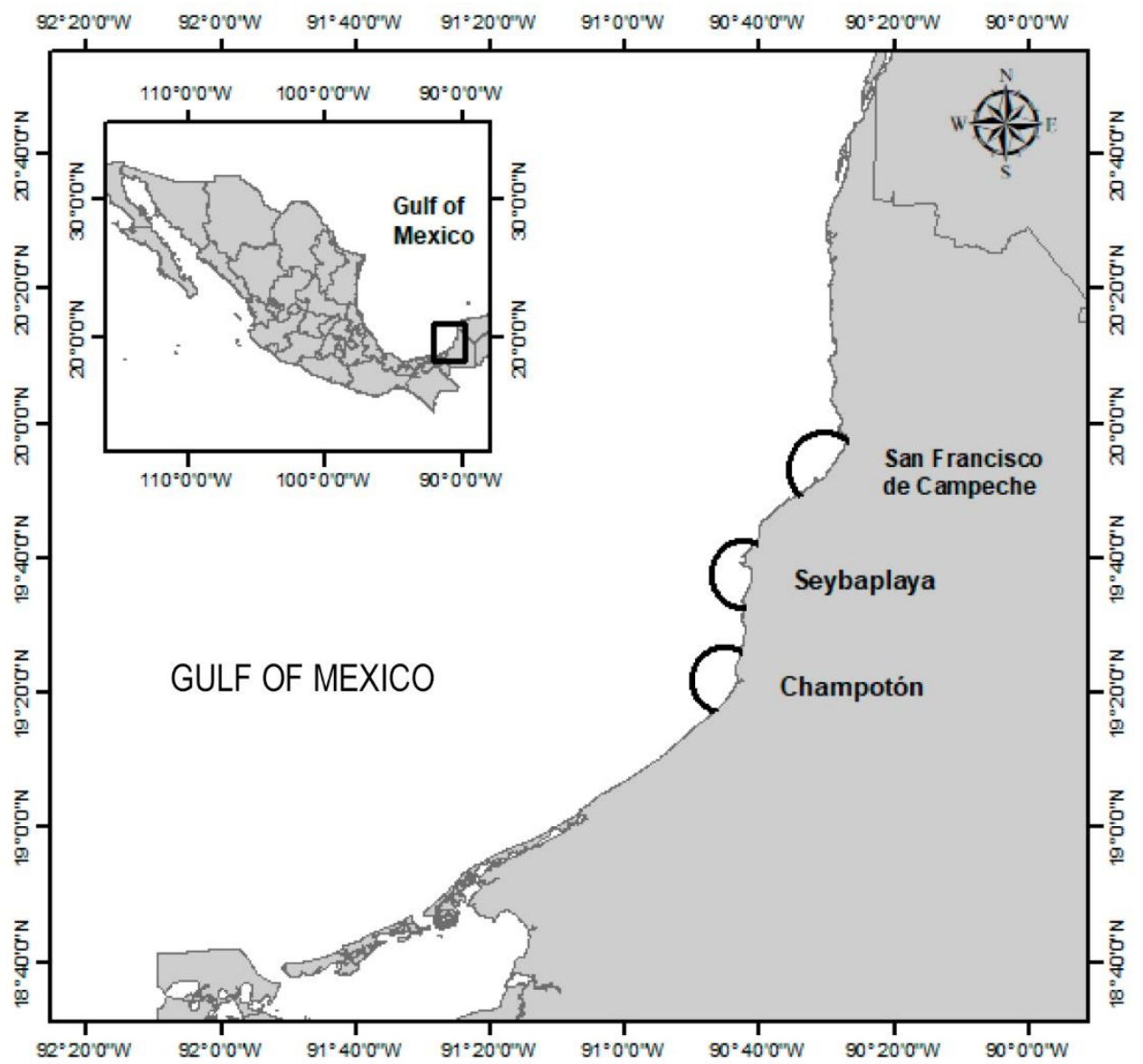

Figure 1. Map showing the study area. The semicircles indicate the extent of the fishing area of the artisanal Mexican fleet for each location.

(1978), Reséndez (1981a,b), and Christensen et al., (1992). Crustaceans were identified based on Fisher (1978), and Pérez \& Kensley (1997). Once the prey items were identified, we collected the dorsal white muscle of those prey species digestion states 1 for the isotopic mixing model analysis.

For isotopic analyses $\left(\delta^{13} \mathrm{C} \& \delta^{15} \mathrm{~N}\right)$ snapper species and prey, tissues were placed in vials fitted and: 1 ) dried for $48 \mathrm{~h}$ in a Thermo Scientific forced convection oven (OMS 60) at $55^{\circ} \mathrm{C}$ to eliminate moisture, then 2) dry samples were ground in an agate mortar, and subsample (1 mg) were weighed and stored in tin capsules $(8 \times 5 \mathrm{~mm})$ in a Radwag analytical microbalance. The $\delta^{13} \mathrm{C}$ and $\delta^{15} \mathrm{~N}$ compositions were determined at the Mass Spectrometry Laboratory (LESMA) of the Centro Interdisciplinario de Ciencias Marinas (CICIMAR) at Instituto Politécnico Nacional (IPN), Mexico, using an Isotope Ratio Mass Spectrometer (Thermo Scientific Delta V Plus) with a precision of $0.1 \%$.

Stable isotope values $(\delta)$ were calculated using the formula proposed by Park \& Epstein (1961):

$$
\delta^{15} \mathrm{~N} \text { or } \delta^{13} \mathrm{C}(\% 0)=\left[\left(\frac{\text { Rsample }}{\text { Rstandard }}\right)-1\right] \times 1000
$$

where, Rsample is the isotopic ratio of the heaviest stable isotope relative to the lightest $\left(\delta^{13} \mathrm{C} / \delta^{12} \mathrm{C}\right.$ or $\delta^{15} \mathrm{~N} / \delta^{14} \mathrm{~N}$ respectively) in the sample and Rstandard is the value of the isotopic ratio for a known standard: Vienna Pee Dee Belemnite (VPDB) for carbon and atmospheric $\mathrm{N}^{2}$ for nitrogen.

\section{Data analysis}

\section{Cumulative curves (CV's) and $\mathrm{C}: \mathrm{N}$ ratio}

For stomach contents analysis, cumulative prey curves (Ferry \& Cailliet, 1996) were generated in the Estimates program (Colwell, 2006) based on Hoffman (1979) to determine whether the number of stomachs analyzed was adequate to represent the trophic spectrum. Also, the coefficient of variation was calculated as an indicator of diet variability, with a CV $<0.05$ whether the number of stomachs analyzed was adequate to represent the trophic spectrum of Lutjanus synagris and L. griseus (Steel \& Torrie, 1992). For 
stable isotopes analysis, the $\mathrm{C}: \mathrm{N}$ ratios were used to determine whether samples had a low lipid content, assuming that values between 2.5 and 3.5 indicate less than $5 \%$ of lipid concentration in the tissue, which does not alter the isotopic signal (Post et al., 2007) significantly.

\section{Estimates of feeding habits variability}

To detect intraspecific diet variation, we sorted $L$. synagris and L. griseus data by sex, location (San Francisco de Campeche, Seybaplaya, and Champotón), climatic seasons (dry, rainy, and wind/winter) and months. For stable isotopes, we sorted by sex, location, and climatic season. For stomach content analysis, the prey-specific index of relative importance (\%PSIRI) was calculated with the formula: $\%$ PSIRI $=(\% \mathrm{PNi}+$ $\mathrm{PWi}) \times \% \mathrm{FO}$, where $\% \mathrm{FO}$ is the percent frequency of occurrence (the number of stomachs containing prey $\mathrm{i}$ divided by the total number of stomachs, $\mathrm{n}$ ), and \% PNi and $\% \mathrm{PWi}$ are the prey-specific abundances by number or weight, respectively (Brown et al., 2012).

For stable isotopes analysis, we estimated the contribution of each prey type to the diet by using the Bayesian mixing model (MixSiar v.1.0.4), which takes into account isotopic errors by using as inputs all $\delta^{13} \mathrm{C}$ and $\delta^{15} \mathrm{~N}$ values of predators and the mean \pm standard deviation (SD) of $\delta^{13} \mathrm{C}$ and $\delta^{15} \mathrm{~N}$ values of the prey types. For this analysis, we followed the criteria established by Phillip et al. (2003), where isotopic values of at less six main prey species (which contributed $>90 \%$ of the diet) were used to make the Bayesian mixing model. This analysis's results were reported as the distribution of percentages ranging from 0 to $99 \%$, where the minimum and maximum values are used to determine the importance of food sources or prey types to the diet (Madigan et al., 2012).

\section{Estimates of niche widths and trophic overlap}

Based on stomach contents, the trophic niche width was evaluated using Levin's standardized index, "Bi'" (Krebs, 1999), which ranges from 0 to 1 , with low values $(<0.6)$ indicating the diet was dominated by few prey items (specialist predator), and high values $(>0.6)$ indicating a generalist predator (Labropoulou \& Eleftheriou, 1997). The feeding strategy was also evaluated using the graphs of Costello (1990) modified by Amundsen et al. (1996), containing the prey specific abundance $(\% \mathrm{PNi})$ and frequency of occurrence $(\% \mathrm{FO})$ plotted with points for prey categories (Brown et al., 2012). According to Amundsen et al. (1996), four feeding strategies were described: 1) specialize in individual prey types, 2) more generalized diet and higher within-individual variation in diet breadth, 3) specialization on a single prey type while occasionally consuming other prey, and 4) mixed feeding strategy in which some individuals have a specialized diet and other fish have a more generalized feeding strategy.

For the intraspecific trophic overlap (sex, location, climatic season, and months) and between $L$. synagris and L. griseus (interspecific comparison), a nonparametric multivariate analysis of variance permutation (PERMANOVA) was carried out. This analysis was applied with the Adonis function of the vegan package (Oksanen et al., 2015) in R (R Core Team, 2014). Subsequently, with the PRIMER v.6. software, a similarity percentage analysis (SIMPER) was applied to determine the trophic items responsible for the differences in the diets for each category analyzed. This analysis calculates the average of the differences between species and records each category's contribution to this inequality (Clarke \& Warwick, 1994). Monthly average sea surface temperature (SST) data from 2015 was used to analyze the possible variations of $L$. griseus and $L$. synagris diets associated with changes in SST. This data was obtained by the NOAA and the NCDC (National Climatic Data Centerhttps://www.ncdc.noaa.gov/data-access).

Based on stable isotopes analysis, the SIBER method (Euclidean distance) was used for calculating the ellipse-based metrics of trophic overlap and isotopic niche widths for $L$. synagris and L. griseus (Jackson, 2011) available in R (R Core Team, 2014). For isotopic niche width $(\mathrm{NW})$, values $<1$ reflect a broad trophic niche; for trophic overlap, values $>1$ indicate considerable overlap between species (Bearhop et al., 2004). Also, our stable isotope data failed the assumptions of normality (Shapiro-Wilk test) and homogeneity of variance (Levene's test); therefore, a Mann-Whitney test was used to detect intraspecific variation between sex and Kruskal-Wallis test was used to detect interspecific variation (location and season). Statistical analyses were performed in Statistica v.8.0, with the significance level set to $P<0.05$.

\section{Estimates of trophic level and position}

The trophic level (TL) based on stomach content was calculated using the equation proposed by Christensen \& Pauly (1992);

$$
\mathrm{TL}=1+\left(\sum_{j=1}^{n} \mathrm{DC}_{j i}\right)\left(\mathrm{TL}_{j}\right)
$$

where, $\mathrm{DC}_{j i}$ : diet composition in weight, in terms of the prey proportion $(j)$ in the predator's $\operatorname{diet}(i) ; \mathrm{TL}_{j}$ : trophic position of prey species $j$; and $\mathrm{n}$ is the number of prey groups in the diet. In this equation, trophic position values for fish species were obtained from FishBase (Froese \& Pauly, 2010), and those for cephalopods, crustaceans' species were obtained from Cortés (1999). 
We calculated the trophic position (TP) for $L$. synagris and $L$. griseus using isotope values with the equation proposed by Post (2002). We select prey species which, according to Post (2002), should be present in the area and in the diet of the predator; its TP value should preferably be higher than 2 .

Therefore, the $\delta^{15} \mathrm{~N}_{\text {base }}(2.9 \%)$ used for the trophic position at the base of the food web was the pink shrimp (Farfantepenaeus duorarum), a crustacean captured in the littoral of Campeche and present in the diet of $L$. synagris and L. griseus.

For $F$. duorarum was assigned a trophic position of 2.8 (calculated in the present study), and for all trophic estimations, enrichment $(\Delta)$ in $\delta^{15} \mathrm{~N}$ was assumed to be $3.0 \%$ (Rooker et al., 2006) per trophic level:

$$
T P=\lambda+\left[\frac{\delta^{15} N_{\text {predator }}-\delta^{15} N_{\text {Base }}}{\Delta_{n}}\right]
$$

where, $\lambda$ : trophic position for the base (2.8 for $F$. duorarum), $\Delta$ : theoretical value for ${ }^{15} \mathrm{~N}$-enrichment per trophic level (3.0; according to Rooker et al., 2006), $\delta^{15} \mathrm{~N}_{\text {Predator: }} \delta^{15} \mathrm{~N}$ value of each $L$. synagris and $L$. griseus, $\delta^{15} \mathrm{~N}_{\text {Base: }} \delta^{15} \mathrm{~N}$ value for $F$. duorarum.

\section{RESULTS}

A total of 781 specimens (528 Lutjanus synagris and 253 L. griseus) were sampled, ranging from 20.0 to $40.0 \mathrm{~cm}$ FL with a mean size of $29.5 \pm 4.1 \mathrm{~cm}$ for both snapper species. No significant difference was found in size classes between $L$. synagris and L. griseus $(\mathrm{U}=$ $10.00, P>0.05)$; thus, all specimens were considered adults, and no comparison was made between size classes.

A total of 491 individuals (Table 1) contained food (359 for L. synagris and 124 for L. griseus), where Champoton was the location with more stomachs collected (40.6\%), followed by Seybaplaya (34.3\%) and San Francisco de Campeche (25.0\%). L. synagris present a higher number of stomachs with content in $\mathrm{D}$ $(n=102)$ and $\mathrm{N}$ season $(n=198)$ than L. griseus $(n=12$ and 15 , respectively); however, in $\mathrm{R}$ season both species present a similar number of stomachs with content ( $n=75$ and 60, respectively). For the isotopic composition, 59 muscle samples of $L$. synagris and 49 muscle samples of $L$. griseus were analyzed.

\section{Cumulative curves (CV's), $\mathrm{C}: \mathrm{N}$ ratio, digestive state of prey species and percentage of filling}

The prey species (items) accumulation curve showed that the number of stomachs analyzed was enough to characterize the diet of $L$. synagris and L. griseus (Fig. 2), with CV's less than 0.05 for all categories (i.e., sexes, size-classes, location and season). The $\mathrm{C}: \mathrm{N}$ ratio for muscle presented an average value of 3.2 (Table 1), which corresponds to low lipid concen-trations in the tissue (Post et al., 2007). Thus, the effect of lipid content on the $\delta^{13} \mathrm{C}$ values in this study was considered negligible, and the chemical extraction of lipids before isotopic analysis or an arithmetic correction was not required. The prey's state of digestion was mostly in state $2(40 \%)$ and $3(30 \%)$ for both snapper species, whereas the percentage of filling was mostly in states 1 and 2 (Table 2).

\section{Trophic spectrum and isotopic composition}

The trophic spectrum of L. synagris comprised one bivalve, one gastropod, one cephalopod, 34 crustaceans, and 22 fish species (Table 3 ). $\delta^{15} \mathrm{~N}$ values ranged from 10.6 to $12.1 \%$ with an average of $11.5 \pm 0.5 \%$, while $\delta^{13} \mathrm{C}$ values ranged from -15.7 to $-12.7 \%$ with an average of $-14.7 \pm 0.9 \%$ (Table 4). According to \%PSIRI (Fig. 3), the most important prey items were Penaeus spp. (23.4\%), fish (23\%) and Callinectes sapidus $(13.4 \%)$.

The trophic spectrum of $L$. griseus comprised one gastropod, one cephalopod, 14 crustacean, and 16 fish species (Table 3). $\delta^{15} \mathrm{~N}$ values ranged from 9.8 to $12.9 \%$, with an average of $10.9 \pm 1.0 \%$. $\delta^{13} \mathrm{C}$ values ranged from -13.8 to $-11.4 \%$, with an average of -12.9 $\pm 0.8 \%$ o (Table 4). According to \%PSIRI (Fig. 3), the most important prey items were Callinectes sapidus (21.5\%), fish (20.5\%), Penaeus spp. (15\%), and Farfantepenaeus duorarum (6.1\%) present in most months.

Intraspecific variation for $\boldsymbol{L}$. synagris and $\boldsymbol{L}$. griseus For L. synagris, PERMANOVA indicated high similarity in diets between sex $(P>0.05)$, but low similarity between fishing locations $(P<0.05)$ and climatic seasons $(P<0.05)$. According to SIMPER, the trophic group that contributed to the dissimilarity among fishing locations (specifically between San Francisco de Campeche vs. Seybaplaya and Champoton) was the Penaeidae family (relative contribution $=14.7$ and $15.5 \%$, respectively); whereas, among climatic seasons (specifically between $\mathrm{N} v s$. R and D) was the Penaeidae family (relative contribution $=20.3$ and $20.6 \%$, respectively) and Callinectes spp. (relative contribution $=17.2$ and $15.8 \%$, respectively). Based on stable isotopes, no significant differences were found between sex for $\delta^{15} \mathrm{~N}\left(\mathrm{U}=22.00, P>0.05\right.$, and $\delta^{13} \mathrm{C}(\mathrm{U}$ $=4.50, P>0.05)$, and among climatic seasons for $\delta^{13} \mathrm{C}$ $(\mathrm{H}=2.94, P>0.05)$, but significant differences were found for $\delta^{15} \mathrm{~N}(\mathrm{H}=8.68, P<0.05)$. Also, significant differences were found among locations for $\delta^{13} \mathrm{C}(\mathrm{H}=$ $12.68, P<0.05)$ and $\delta^{15} \mathrm{~N}(\mathrm{H}=9.12, P<0.05)$. 
Table 1. Lutjanus synagris and L. griseus analyzed stomachs in different locations and climatic seasons. W: wind/winter season; D: dry, R: rainy season, TS: total stomachs, ES: empty stomach, SC: stomach with content and C:N = C:N ratio.

\begin{tabular}{lccrrrr}
\hline Species & Location & Season & (TS) & ES & SC & C:N \\
\hline L. synagris & Champoton & $\mathrm{W}$ & $(147)$ & 115 & 32 & 2.7 \\
& & $\mathrm{D}$ & $(68)$ & 53 & 15 & 2.5 \\
& & $\mathrm{R}$ & $(65)$ & 35 & 30 & 2.8 \\
\hline \multirow{4}{*}{ San Francisco de Campeche } & $\mathrm{W}$ & $(55)$ & 32 & 23 & 2.9 \\
& & $\mathrm{D}$ & $(47)$ & 34 & 13 & 2.7 \\
& & $\mathrm{R}$ & $(47)$ & 28 & 19 & 2.8 \\
\hline \multirow{4}{*}{ Seybaplaya } & $\mathrm{W}$ & $(63)$ & 46 & 17 & 2.8 \\
& & $\mathrm{D}$ & $(29)$ & 22 & 7 & 2.7 \\
& & $\mathrm{R}$ & $(44)$ & 20 & 24 & 2.6 \\
\hline & Chiseus & $\mathrm{W}$ & $(26)$ & 12 & 14 & 2.8 \\
& & $\mathrm{D}$ & $(77)$ & 65 & 12 & 2.8 \\
& & $\mathrm{R}$ & $(89)$ & 36 & 53 & 2.7 \\
\hline & & $\mathrm{W}$ & $(17)$ & 7 & 10 & 2.8 \\
& & $\mathrm{D}$ & $(31)$ & 23 & 8 & 2.7 \\
& & $\mathrm{R}$ & $(32)$ & 14 & 18 & 2.8 \\
\hline & & $\mathrm{W}$ & $(15)$ & 7 & 8 & 2.7 \\
& & $\mathrm{D}$ & $(27)$ & 21 & 6 & 2.6 \\
& & $\mathrm{R}$ & $(33)$ & 12 & 21 & 2.5 \\
\hline
\end{tabular}
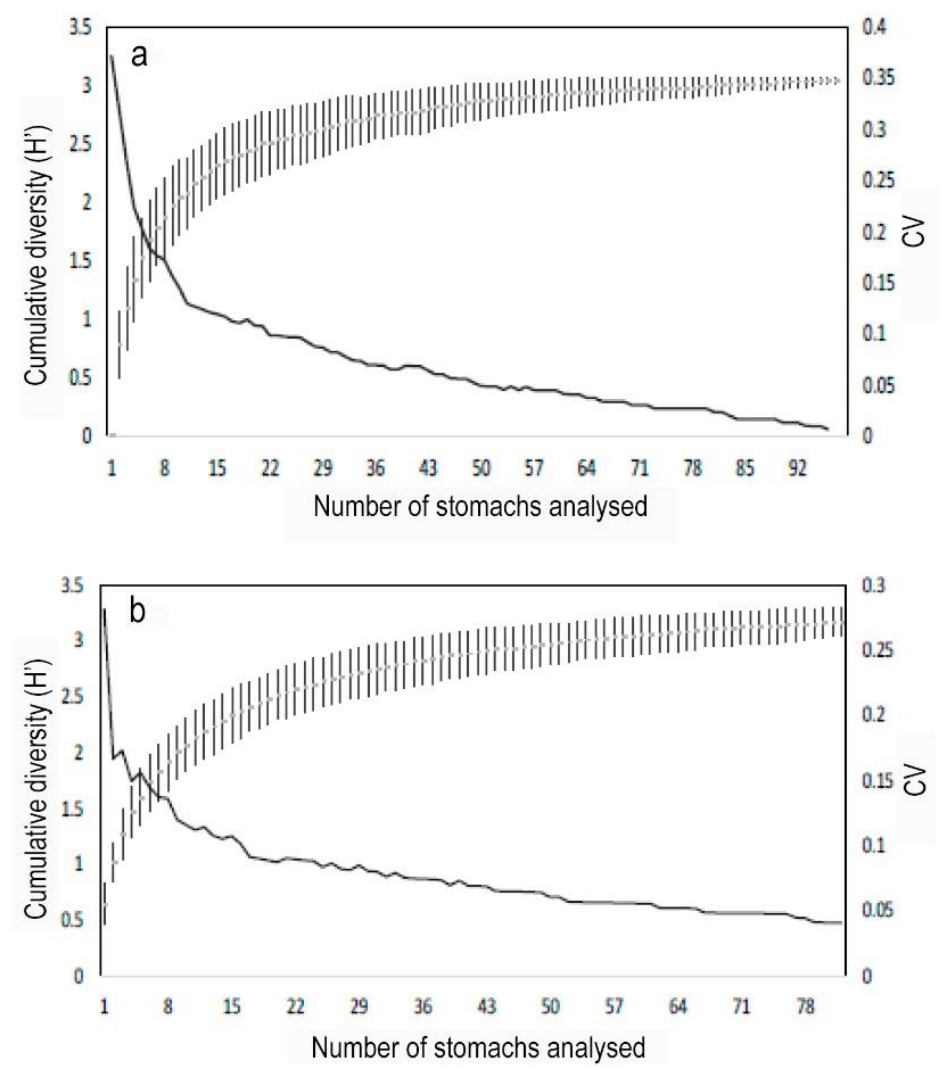

Figure 2. Diversity cumulative curve of prey species of a) Lutjanus griseus and b) L. synagris in the littorals of Campeche, Mexico.

For L. griseus, PERMANOVA indicated high similarity in diets between sex $(P>0.05)$, but between fishing locations $(P<0.05)$ and climatic seasons $(P<$
0.05) a similarity of means was determined. Based on stable isotopes, no significant differences were found between sex $\left[\delta^{15} \mathrm{~N}(\mathrm{U}=34.00, P>0.05)\right.$ and $\delta^{13} \mathrm{C}(\mathrm{U}=$ 
Table 2. Number of prey groups recorded in the digestive stages ("DS" from 1 to 4) present in Lutjnaus synagris and $L$. griseus (separated by "/") in the different location and season. F: fish, Cr: crustaceans, Ot: others (algae, organic matter, echinoderms); W: wind/winter season; D: dry; A: rainy season.

\begin{tabular}{|c|c|c|c|c|c|c|c|}
\hline \multirow{2}{*}{$\begin{array}{l}\text { Species } \\
\text { L. synagris / L. griseus }\end{array}$} & \multirow{2}{*}{ Location } & \multirow{2}{*}{ Season } & \multirow{2}{*}{ Prey species } & \multicolumn{4}{|c|}{ Digestive state } \\
\hline & & & & DS 1 & DS 2 & DS 3 & DS 4 \\
\hline & Champoton & $\mathrm{W}$ & $\mathrm{F}$ & $1 / 0$ & $2 / 2$ & $7 / 1$ & $13 / 2$ \\
\hline & & & $\mathrm{Cr}$ & $4 / 0$ & $36 / 2$ & $50 / 4$ & $19 / 0$ \\
\hline & & & Ot & $0 / 0$ & $0 / 0$ & $1 / 0$ & $11 / 0$ \\
\hline & & $\mathrm{D}$ & $\mathrm{F}$ & $1 / 0$ & $4 / 1$ & $5 / 0$ & $8 / 0$ \\
\hline & & & $\mathrm{Cr}$ & $0 / 0$ & $17 / 2$ & $33 / 0$ & $3 / 0$ \\
\hline & & & Ot & $0 / 0$ & $0 / 1$ & $1 / 1$ & $0 / 2$ \\
\hline & & $\mathrm{R}$ & $\mathrm{F}$ & $1 / 0$ & $2 / 0$ & $7 / 1$ & $10 / 0$ \\
\hline & & & $\mathrm{Cr}$ & $1 / 0$ & $9 / 2$ & $16 / 2$ & $6 / 1$ \\
\hline & & & Ot & $0 / 0$ & $0 / 2$ & $2 / 3$ & $2 / 3$ \\
\hline & San Francisco & $\mathrm{W}$ & $\mathrm{F}$ & $0 / 1$ & $0 / 0$ & $1 / 0$ & $4 / 3$ \\
\hline & de Campeche & & $\mathrm{Cr}$ & $0 / 0$ & $2 / 4$ & $5 / 1$ & $1 / 0$ \\
\hline & & & Ot & $0 / 0$ & $1 / 0$ & $1 / 0$ & $7 / 2$ \\
\hline & & $\mathrm{D}$ & $\mathrm{F}$ & $0 / 1$ & $7 / 5$ & $5 / 5$ & $7 / 0$ \\
\hline & & & $\mathrm{Cr}$ & $0 / 4$ & $15 / 5$ & $4 / 1$ & $0 / 0$ \\
\hline & & & $\mathrm{Ot}$ & $0 / 0$ & $1 / 0$ & $3 / 0$ & $0 / 0$ \\
\hline & & $\mathrm{R}$ & $\mathrm{F}$ & $0 / 0$ & $5 / 3$ & $7 / 3$ & $13 / 2$ \\
\hline & & & $\mathrm{Cr}$ & $0 / 0$ & $7 / 0$ & $11 / 2$ & $1 / 0$ \\
\hline & & & Ot & $0 / 0$ & $2 / 0$ & $1 / 2$ & $7 / 2$ \\
\hline & Seybaplaya & $\mathrm{W}$ & $\mathrm{F}$ & $0 / 0$ & $4 / 2$ & $2 / 1$ & $8 / 1$ \\
\hline & & & $\mathrm{Cr}$ & $0 / 0$ & $29 / 1$ & $14 / 4$ & $1 / 0$ \\
\hline & & & Ot & $0 / 0$ & $0 / 0$ & $0 / 0$ & $0 / 0$ \\
\hline & & D & $\mathrm{F}$ & $1 / 0$ & $2 / 3$ & $1 / 2$ & $14 / 0$ \\
\hline & & & $\mathrm{Cr}$ & $3 / 1$ & $21 / 4$ & $38 / 0$ & $7 / 0$ \\
\hline & & & Ot & $1 / 0$ & $0 / 1$ & $0 / 0$ & $0 / 0$ \\
\hline & & $\mathrm{R}$ & $\mathrm{F}$ & $0 / 0$ & $0 / 2$ & $1 / 1$ & $7 / 3$ \\
\hline & & & $\mathrm{Cr}$ & $0 / 0$ & $10 / 10$ & $17 / 7$ & $0 / 1$ \\
\hline & & & $\mathrm{Ot}$ & $0 / 0$ & $0 / 0$ & $3 / 0$ & $0 / 0$ \\
\hline
\end{tabular}

$18.00, P>0.05)]$, climatic seasons $\left[\delta^{15} \mathrm{~N}(\mathrm{H}=0.58\right.$, $P>0.05)$ and $\left.\delta^{13} \mathrm{C}(\mathrm{H}=4.93, P>0.05)\right]$, and location for $\delta^{13} \mathrm{C}(\mathrm{H}=4.81, P>0.05)$; however, significant diffe-rences were found for $\delta^{15} \mathrm{~N}(\mathrm{H}=14.22, P<0.05)$.

The interspecific variation between $L$. synagris and L. griseus (niche width, trophic overlap, and trophic position)

For L. synagris and L. griseus, niche width (Bi) values were $<0.6$ for all categories (Table 5), while Costello's graphs show that both lutjanids species specialize on individual prey types (feeding strategies I; Fig. 4). According to SIBER, L. synagris in $\mathrm{W}$ present generalist behavior $(\mathrm{NW}>1)$ while in $\mathrm{D}$ and $\mathrm{R}$ present specialist behavior NW < 1; (Fig. 5). For L. griseus, SIBER indicated a generalist behavior in San Francisco de Campeche (NW > 1), but a specialist behavior in Seybaplaya and Champoton (NW < 1; Fig. 6).
For the trophic overlap, PERMANOVA indicated low similarity between $L$. synagris and $L$. griseus in abundance $(P<0.05)$ among months. According to SIMPER, the trophic groups that contributed to the similarity in abundance were Penaeidae (15.7\%), Callinectes spp. (13.7\%), and Portunus spp. (8.7\%). Based on isotopes stables, no significant differences were found between $L$. synagris and $L$. griseus for $\delta^{15} \mathrm{~N}$ $(\mathrm{U}=34.00, P>0.05)$ and $\delta^{13} \mathrm{C}(\mathrm{U}=18.00, P>0.05)$. SIBER analysis confirms a low trophic overlap in general (0.14; Fig. 7).

The trophic level for L. synagris obtained from stomach contents was $3.7 \pm 0.3$, and the trophic position based on stable isotopes was $4.2 \pm 0.2$, while for $L$. griseus, the trophic level obtained from stomach contents was $3.8 \pm 0.1$ and the trophic position based on stable isotopes was $3.9 \pm 0.1$ (Table 5).

Preys contribution for $L$. synagris and $L$. griseus The prey's values $\left(\delta^{13} \mathrm{C}\right)$ in San Francisco de Campeche were recorded from -11.2 to -13.4 and $\delta^{15} \mathrm{~N}$ from 3.8 to 

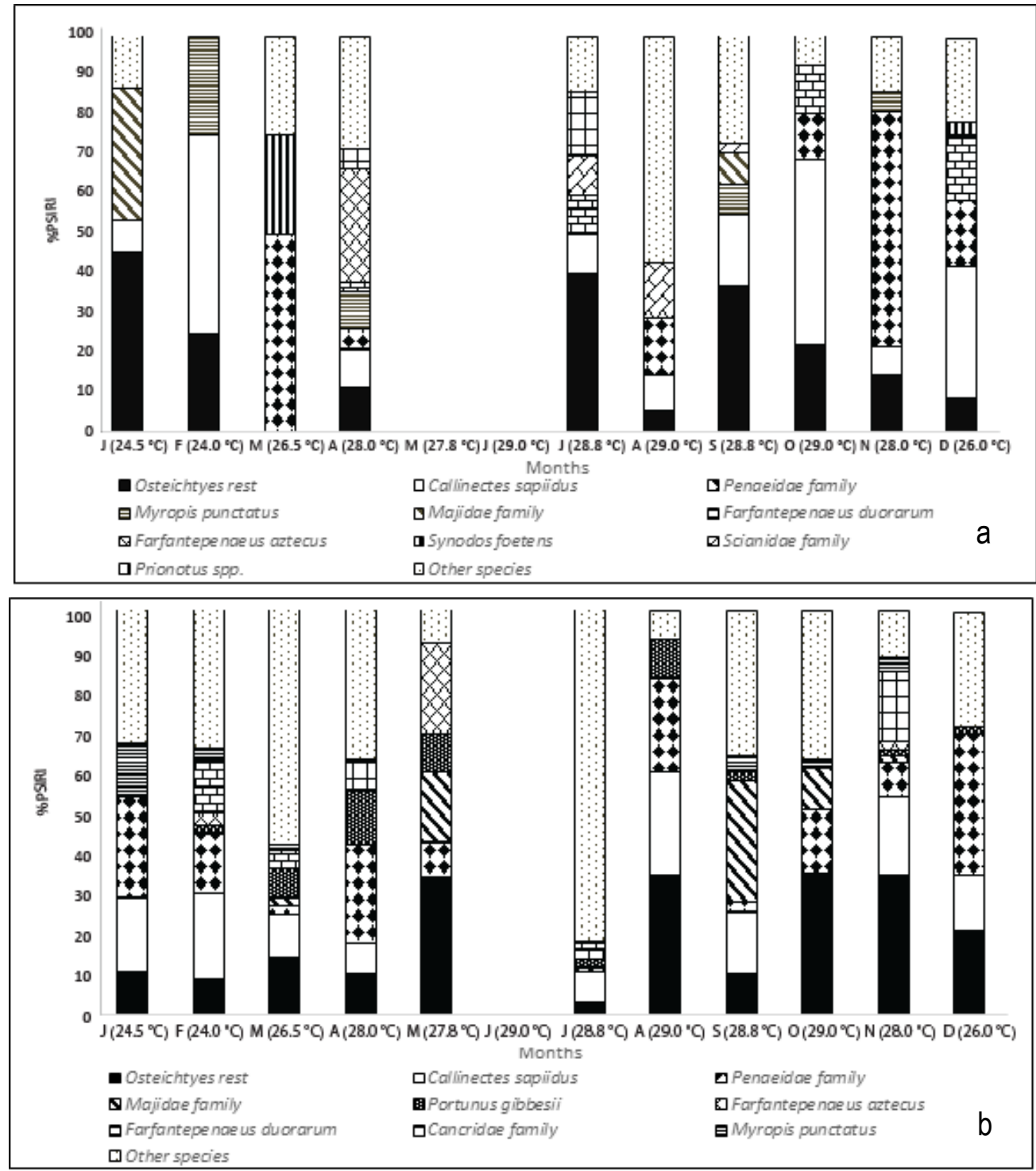

Figure 3. Diets contributions (\%PSIRI) and sea surface temperature "SST" (National Climatic Data Center) by months for a) Lutjanus griseus and b) L. synagris in the littoral of Campeche, Mexico.

9.0. In Seybaplaya, $\delta^{13} \mathrm{C}$ from -10.4 to -16.4 and $\delta^{15} \mathrm{~N}$ from 5.8 to 8.1 , Champoton $\delta^{13} \mathrm{C}$ from -11.8 to -16.7 , and $\delta^{15} \mathrm{~N}$ from 4.8 to 10.1 (Table 6 ). The mixing models (MixSiar) indicated that the most important trophic groups of L. synagris were: Farfantepenaeus duorarum (10-63\%), Squilla empusa (0-50\%) and Callinectes spp. (0-40\%), whereas, for L. griseus were Farfantepenaeus duorarum (0-63\%), Callinectes spp. (0-55\%) and Squilla empusa (0-60).

\section{DISCUSSION}

The individuals analyzed were considered adults due to the recorded sizes since snappers generally reach sexual maturity of approximately $23 \mathrm{~cm}$ (Brulé et al., 2004). In both species, the filling percentage was low (30\%) and with a medium degree of digestion, as has been reported for other species of the genus (Lutjanus peru; Santamaría-Miranda et al., 2003). It was related due to the carnivorous fish have an evolved stomach that secretes acids to quickly digest bone, meat, and scales of ingested prey, it has a much shorter intestine than herbivores, causing digestion to be faster (Lagler et al., 1984). The presence of a high number of stomachs with low content has made it difficult for years to study the diet in different species; however, in the present study, the analysis of stable isotope analysis helped understand the feeding habits variability of both snapper species. 
Table 3. The trophic spectrum of Lutjanus synagris and L. griseus, expressed in percentages values of the prey-specific abundances by number (\%PNi), prey-specific abundances by weight (\%PWi), and frequency of occurrence (\%FO) and prey-specific index of relative importance (\%PSIRI); UOM: unidentified organic matter.

\begin{tabular}{|c|c|c|c|c|c|c|c|c|c|}
\hline \multirow{2}{*}{ Phylum } & \multirow{2}{*}{ Species } & \multicolumn{4}{|c|}{ L. synagris } & \multicolumn{4}{|c|}{ L. griseus } \\
\hline & & $\% \mathrm{PNi}$ & $\% \mathrm{PWi}$ & $\% \mathrm{FO}$ & \%PSIRI & $\% \mathrm{PNi}$ & $\% \mathrm{PWi}$ & $\% \mathrm{FO}$ & \%PSIRI \\
\hline Antophyta & Thalassia testudinum & - & - & - & - & 38.8 & 9 & 3 & 0.7 \\
\hline Mollusca & Octopus maya & 56.6 & 62.4 & 0.8 & 0.5 & 100 & 100 & 1 & 1 \\
\hline \multirow[t]{24}{*}{ Arthropoda } & Squilla empusa & 53.3 & 79.5 & 0.8 & 0.5 & - & - & - & - \\
\hline & Penaeus spp. & 77.6 & 67.2 & 32.3 & 23.4 & 94.2 & 92.8 & 13.2 & 15 \\
\hline & Farfantepenaeus duorarum & 71.1 & 72.9 & 3.9 & 2.8 & 95.8 & 89.1 & 6.1 & 6.4 \\
\hline & Farfantepenaeus aztecus & 70 & 60.2 & 1.4 & 0.9 & 100 & 100 & 6.1 & 6.1 \\
\hline & Trachypenaeus constrictus & 94.2 & 92 & 1.1 & 1 & - & - & - & - \\
\hline & Penaeus vannamei & 75 & 57.1 & 0.3 & 0.1 & - & - & - & - \\
\hline & Litopenaeus setiferus & 61.6 & 59.7 & 1.4 & 0.8 & - & - & - & - \\
\hline & Sicyonia typica & 30.5 & 8.6 & 0.5 & 0.1 & - & - & - & - \\
\hline & Tethraxantus spp. & 100 & 100 & 0.3 & 0.3 & - & - & - & - \\
\hline & Pagurus bernhardus & 100 & 100 & 0.5 & 0.5 & - & - & - & - \\
\hline & Calappa ocellata & 50 & 68.6 & 0.5 & 0.3 & - & - & - & - \\
\hline & Speocarcinus lobatus & 9 & 4.1 & 0.3 & 0.1 & - & - & - & - \\
\hline & Menipe mercenaria & 61.5 & 59.3 & 1.4 & 0.8 & - & - & - & - \\
\hline & Callinectes spp. & 17.7 & 17.4 & 10.2 & 12 & 6.4 & 5.6 & 0.9 & 2.5 \\
\hline & Callinectes bocourti & 60.1 & 60.5 & 4.2 & 2.5 & - & - & - & - \\
\hline & Callinectes sapidus & 59.4 & 61.5 & 22.1 & 13.4 & 86 & 82.1 & 25.5 & 21.5 \\
\hline & Callinectes danae & 4.6 & 32.6 & 0.5 & 0.1 & 33.3 & 5.5 & 1 & 0.2 \\
\hline & Callinectes similis & 100 & 100 & 0.8 & 0.8 & - & - & - & - \\
\hline & Callinectes rathbunae & 52.3 & 50.8 & 0.8 & 0.4 & - & - & - & - \\
\hline & Portunus spinnimanus & 49.4 & 53.8 & 2.5 & 1.3 & - & - & - & - \\
\hline & Portunus gibbesii & 52.8 & 53.2 & 7.8 & 4.1 & 83.3 & 84.6 & 3 & 3.5 \\
\hline & Pilumnus dasypodus & 75 & 58 & 0.5 & 0.3 & - & - & - & - \\
\hline & Myropsis quinquespinosa & 41.1 & 36.1 & 3 & 1.1 & - & - & - & - \\
\hline & Hepatus epheliticus & 48.1 & 57.5 & 3 & 1.6 & - & - & - & - \\
\hline \multirow[t]{24}{*}{ Chordata } & Ariopsis felis & 33.3 & 52.3 & 0.2 & 0.1 & - & - & - & - \\
\hline & Bagre marinus & 50 & 56.1 & 0.5 & 0.3 & - & - & - & - \\
\hline & Achirus achirus & 100 & 100 & 0.2 & 0.2 & - & - & - & - \\
\hline & Opsanus beta & 100 & 100 & 0.5 & 0.5 & 75 & 82 & 2 & 2.5 \\
\hline & Harengula jaguana & 50 & 84 & 0.2 & 0.1 & 66.6 & 52.8 & 2 & 1.2 \\
\hline & Symphurus plagiusa & 25 & 30.7 & 0.2 & 0.1 & - & - & - & - \\
\hline & Anchoa spp. & 0.6 & 0.4 & 0.5 & 0.1 & - & - & - & - \\
\hline & Eucinostomus gula & 50 & 65.8 & 0.5 & 0.3 & - & - & - & - \\
\hline & Ocyurus chrysurus & 25 & 9.3 & 0.2 & 0.1 & - & - & - & - \\
\hline & Citharichthys macrops & - & - & - & - & 50 & 60 & 1 & 0.5 \\
\hline & Monacanthus ciliatus & 100 & 100 & 0.5 & 0.5 & 50 & 68.4 & 1 & 1 \\
\hline & Myrophis punctatus & 57.5 & 58.2 & 4.2 & 2.4 & 85 & 89 & 5.1 & 6 \\
\hline & Synodus foetens & - & - & - & - & 75 & 67.9 & 2 & 2 \\
\hline & Hippocampus erectus & 50 & 92.3 & 0.2 & 0.2 & - & - & - & - \\
\hline & Syngnathus louisianae & 50 & 14.5 & 0.2 & 0.1 & 50 & 31.5 & 1 & 0.5 \\
\hline & Starksia spp. & 50 & 8.9 & 0.2 & 0.1 & - & - & - & - \\
\hline & Diplectrum formosum & 25 & 76 & 0.3 & 0.1 & - & - & - & - \\
\hline & Odontoscion dentex & 50 & 77.4 & 0.3 & 0.2 & 100 & 100 & 1 & 1 \\
\hline & Menticirrhus saxatilis & - & - & - & - & 100 & 100 & 2 & 2 \\
\hline & Lagodon rhomboides & - & - & - & - & 100 & 100 & 1 & 1 \\
\hline & Archosargus rhomboidalis & - & - & - & - & 100 & 100 & 1 & 1 \\
\hline & Scarus spp. & - & - & - & - & 25 & 65 & 1 & 0.4 \\
\hline & Prionotus spp. & 57.5 & 48.9 & 1.6 & 0.9 & 83.3 & 90.6 & 3 & 2.6 \\
\hline & Urobatis jamaicensis & 50 & 98.1 & 0.2 & 0.2 & - & - & - & - \\
\hline \multirow[t]{3}{*}{ Other groups } & Bivalves & 61.1 & 51.8 & 0.8 & 0.4 & - & - & - & - \\
\hline & Gastropods & 100 & 100 & 0.2 & 0.2 & 100 & 100 & 1 & 1 \\
\hline & Fish & 25 & 72.8 & 81.3 & 23 & 83.7 & 90.6 & 23.4 & 20.4 \\
\hline UOM & - & 50 & 9 & 0.2 & 0.1 & - & - & - & - \\
\hline
\end{tabular}

Despite the high number of stomachs with low content, the trophic groups reported in Lutjanus synagris (33 species of crustaceans, 22 fish and mollusks) and $L$. griseus (13 species of crustaceans, 16 
Table 4. Isotopic composition $\left(\delta^{13} \mathrm{C}\right.$ and $\delta^{15} \mathrm{~N}$ presented in \%o) of Lutjanus synagris and L. griseus. W: wind/winter season, D: dry, R: rainy season, SD: standard deviation.

\begin{tabular}{|c|c|c|c|c|c|c|}
\hline Specie & Location & Season & $\mathrm{n}$ & Length (mean $\pm \mathrm{SD})$ & $\delta^{13} \mathrm{C}(\%) \pm \mathrm{SD}$ & $\delta^{15} \mathrm{~N}(\%) \pm \mathrm{SD}$ \\
\hline \multirow[t]{10}{*}{ L. synagris } & General & & 59 & $29.6 \pm 2.9$ & $-14.7 \pm 0.9$ & $11.5 \pm 0.5$ \\
\hline & San Francisco de Campeche & $\mathrm{W}$ & 5 & $31.9 \pm 3.2$ & $-12.7 \pm 1.1$ & $10.6 \pm 0.5$ \\
\hline & & $\mathrm{D}$ & 6 & $29.6 \pm 3.0$ & $-14.5 \pm 1.0$ & $11.3 \pm 0.5$ \\
\hline & & $\mathrm{R}$ & 7 & $30.0 \pm 2.9$ & $-14.3 \pm 1.0$ & $11.4 \pm 0.6$ \\
\hline & Seybaplaya & $\mathrm{W}$ & 7 & $28.9 \pm 2.1$ & $-15.0 \pm 1.1$ & $11.2 \pm 0.5$ \\
\hline & & $\mathrm{D}$ & 7 & $25.4 \pm 3.1$ & $-15.2 \pm 1.0$ & $12.1 \pm 0.5$ \\
\hline & & $\mathrm{R}$ & 5 & $28.9 \pm 2.1$ & $-14.6 \pm 1.0$ & $11.2 \pm 1.2$ \\
\hline & Champoton & $\mathrm{W}$ & 8 & $30.2 \pm 2.9$ & $-15.7 \pm 1.1$ & $11.8 \pm 0.6$ \\
\hline & & $\mathrm{D}$ & 6 & $30.1 \pm 2.9$ & $-14.8 \pm 1.0$ & $11.6 \pm 0.5$ \\
\hline & & $\mathrm{R}$ & 7 & $30.2 \pm 2.0$ & $-14.5 \pm 1.0$ & $11.6 \pm 0.5$ \\
\hline \multirow[t]{10}{*}{ L. griseus } & General & & 49 & $30.5 \pm 3.2$ & $-12.9 \pm 1.0$ & $10.9 \pm 0.8$ \\
\hline & San Francisco de Campeche & $\mathrm{W}$ & 4 & $32.5 \pm 2.4$ & $-12.4 \pm 0.7$ & $10.8 \pm 0.8$ \\
\hline & & $\mathrm{D}$ & 9 & $29.6 \pm 3.2$ & $-12.7 \pm 0.9$ & $9.8 \pm 0.9$ \\
\hline & & $\mathrm{R}$ & 9 & $32.3 \pm 3.2$ & $-13.6 \pm 1.0$ & $10.8 \pm 0.8$ \\
\hline & Seybaplaya & W & 2 & $30.0 \pm 3.4$ & $-13.5 \pm 1.0$ & $11.5 \pm 0.8$ \\
\hline & & $\mathrm{D}$ & 4 & $25.4 \pm 3.2$ & $-13.8 \pm 1.0$ & $12.9 \pm 0.9$ \\
\hline & & $\mathrm{R}$ & 7 & $31.0 \pm 3.2$ & $-13.2 \pm 0.9$ & $11.3 \pm 0.8$ \\
\hline & Champoton & W & 3 & $30.1 \pm 3.5$ & $-11.4 \pm 1.1$ & $10.2 \pm 0.8$ \\
\hline & & $\mathrm{D}$ & 4 & $29.2 \pm 3.9$ & $-13.4 \pm 0.8$ & $11.5 \pm 0.7$ \\
\hline & & $\mathrm{R}$ & 3 & 30.0 & -13.0 & 11.2 \\
\hline
\end{tabular}

Table 5. Niche width and trophic position of Lutjanus synagris and Lutjanus griseus. SC: stomach content, SI: stable isotopes: SD: standard deviation, W: wind/winter season, D: dry, R: rainy season.

\begin{tabular}{|c|c|c|c|c|c|c|c|}
\hline \multirow{2}{*}{ Specie } & \multirow{2}{*}{ Location } & \multirow{2}{*}{ Season } & \multirow{2}{*}{$\frac{n}{(\mathrm{SC}-\mathrm{SI})}$} & \multicolumn{2}{|c|}{ Niche width } & \multicolumn{2}{|c|}{ Trophic position } \\
\hline & & & & $\mathrm{SC}$ & SI & $\mathrm{SC} \pm \mathrm{SD}$ & $\mathrm{SI} \pm \mathrm{SD}$ \\
\hline \multirow[t]{9}{*}{ L. synagris } & San Francisco de Campeche & WS & $36-4$ & $<0.01$ & 1.1 & $3 \pm 0.6$ & $4 \pm 0.7$ \\
\hline & & $\mathrm{D}$ & $47-9$ & 0.01 & 0.9 & $3.2 \pm 0.5$ & $3.8 \pm 0.5$ \\
\hline & & $\mathrm{R}$ & $61-9$ & 0.02 & 1.2 & $3 \pm 0.6$ & $3.7 \pm 0.4$ \\
\hline & Seybaplaya & $\mathrm{W}$ & $100-2$ & 0.03 & 1.13 & $2.9 \pm 0.6$ & $3.2 \pm 0.5$ \\
\hline & & $\mathrm{D}$ & $76-4$ & 0.2 & 0.7 & $2.8 \pm 0.7$ & $3.4 \pm 0.9$ \\
\hline & & $\mathrm{R}$ & $47-7$ & 0.04 & 0.9 & $3 \pm 0.4$ & $4 \pm 0.5$ \\
\hline & Champoton & $\mathrm{W}$ & $140-3$ & 0.1 & 1 & $4 \pm 0.4$ & $4.1 \pm 0.6$ \\
\hline & & $\mathrm{D}$ & $53-4$ & $<0.01$ & 0.6 & $3.3 \pm 0.5$ & $4.2 \pm 0.5$ \\
\hline & & $\mathrm{R}$ & $64-3$ & 0.03 & 0.9 & $3.5 \pm 0.2$ & $4 \pm 0.1$ \\
\hline \multirow[t]{9}{*}{ L. griseus } & San Francisco de Campeche & $\mathrm{W}$ & $11-5$ & 0.04 & 2.1 & $3.2 \pm 0.6$ & $3.9 \pm 0.1$ \\
\hline & & $\mathrm{D}$ & $14-6$ & 0.1 & 2 & $3 \pm 0.4$ & $3.6 \pm 0.3$ \\
\hline & & $\mathrm{R}$ & $26-7$ & 0.03 & 1.8 & $3.9 \pm 0.2$ & $3.7 \pm 0.2$ \\
\hline & Seybaplaya & $\mathrm{W}$ & $14-7$ & 0.02 & 1.1 & $3 \pm 0.3$ & $3.9 \pm 0.3$ \\
\hline & & $\mathrm{D}$ & $10-7$ & 0.01 & 0.9 & $3.2 \pm 0.4$ & $3.7 \pm 0.4$ \\
\hline & & $\mathrm{R}$ & $25-5$ & 0.03 & 0.9 & $3.8 \pm 0.1$ & $3.8 \pm 0.2$ \\
\hline & Champoton & $\mathrm{W}$ & $9-8$ & $<0.01$ & 0.6 & $3.9 \pm 0.2$ & $3.5 \pm 0.6$ \\
\hline & & $\mathrm{D}$ & $11-6$ & 0.02 & 0.8 & $3.7 \pm 0.1$ & $3.3 \pm 0.6$ \\
\hline & & $\mathrm{R}$ & $11-7$ & 0.02 & 0.9 & $3.8 \pm 0.4$ & $3.9 \pm 0.3$ \\
\hline
\end{tabular}

fish and mollusks), coincide with those reported by Duarte \& Garcia (1999) for L. synagris in Colombia (106 prey species) and Pimentel \& Joyeux (2010) in Brazil (24 prey species). The differences in the number of prey species are possibly due to differences in the diversity-related to sites. For example, the number of crustacean's species identified in the present study is reported in the high diversity of the littoral of Campeche (more than 200 species), which is a fundamental part of the food web for both snappers.

The trophic group with a high contribution (\%PSIRI) in L. synagris and L. griseus were crustaceans, which 

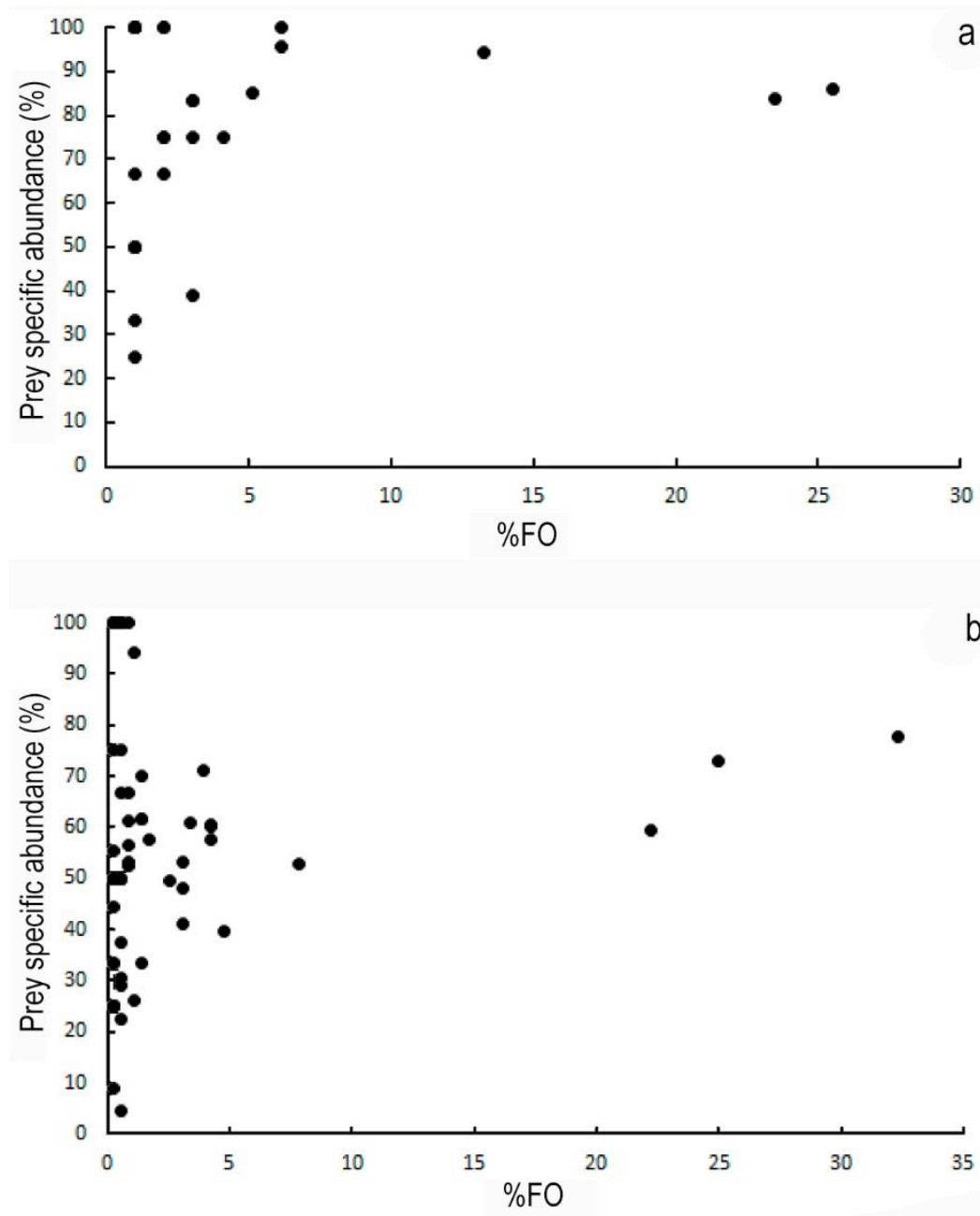

Figure 4. Costello's graph represents the general food strategy and categories of a) Lutjanus griseus and b) L. synagris.

coincides with MixSIAR, previously reported by other authors (Yáñez-Arancibia \& Day, 1986; Harrigan et al., 1989; Hettler, 1989; Rivera-Arriaga, 1993; Guevara et al., 1994; Rooker, 1995; Sierra, 1996; Rojas-Herrera et al., 2004). For example, Guevara et al. (2007) and Juárez (2011) report that preys species $F$. duorarum and other crustaceans are the most important in the diet of these two snapper species. Therefore, the diet of $L$. synagris and L. griseus is mainly based on the consumption of crustaceans.

An optimal foraging model generates estimations of how animals maximize their fitness while they forage. The model building process involves identifying the currency, constraints, and appropriate decision rule for the forager (Stephens \& Krebs, 1986; Sinervo, 1997), and this model allow us to predict how a fish behaves when searching for food. In this sense, some authors indicate that lutjanids have generalist-opportunistic behavior (Duarte \& García, 1999; Rojas-Herrera et al., 2004). However, results obtained in other species of lutjanids, show the low amplitude of the trophic niche $(<0.50)$, denoting specialization in the diet (SaucedoLozano, 2000; Santamaría-Miranda et al., 2005; Guevara et al., 2007). In the present study, the preference for crustaceans and temporal and spatial changes in diet confirm that $L$. synagris and $L$. griseus have trophic plasticity (Costello's graphs). However, with specific selectivity (Levin's index) to abundant trophic groups in the different ecosystems present in the area (seagrasses and mangroves), also, the low isotopic variability (standard deviation) indicated specialization in a particular trophic group (crustaceans), which indicated an ecological strategy for the optimization in the use of trophic resources, to reduce or avoid the level of intraspecific competition (Schoener, 1974; Werner, 1979).

The isotopic composition of $L$. synagris and $L$. griseus indicated that both snapper species could be found in coastal zones with low migration to pelagic zones, being important predators in the coastal ecosys- 


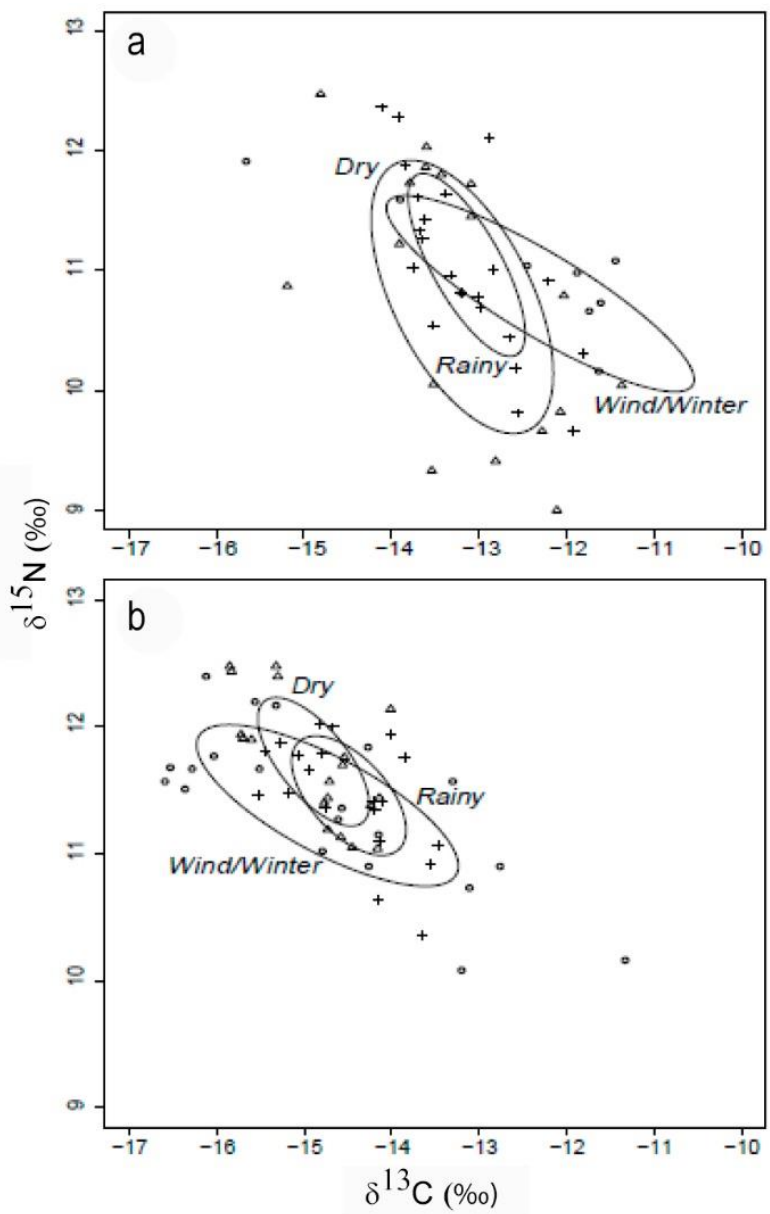

Figure 5. Standard ellipses for the muscle of a) Lutjanus griseus and b) L. synagris among climatic seasons in the littoral of Campeche, Mexico. In both figures, triangles: dry season, circles: wind/winter season, and crosses: rainy season.

tem. In Florida, the isotopic composition $\left(\delta^{15} \mathrm{~N}\right)$ of $L$. synagris and $L$. griseus caught in areas near to mangrove and seagrass were $9.2 \pm 0.4$ and $9.7 \pm 0.8 \%$, respectively (Vaslet et al., 2012). Romo-Ríos (2012) indicated that $L$. synagris its one of the predators with high $\delta^{15} \mathrm{~N}$ value (13\%). Registered in areas with seagrass contributions in Laguna de Terminos, Campeche, which like other species that are distributed in the coastal-marine zone, present values of $\delta^{13} \mathrm{C}$ from -18 to $-10 \%$, probably related to: 1 ) the consumption of preys with intermediate carbon values, and 2) to the ingestion of a combination of depleted and enriched food sources in $\delta^{13} \mathrm{C}$ (Nagelkerken \& Van Der Velde, 2004), related to the daily trophic migrations of fish between mangroves and seagrass beds (Hobson, 1999; Nagelkerken \& Van Der Velde, 2004).

The location where more organisms were collected was Champoton, which is characterized by sandy beaches and limos rich in organic matter products of the

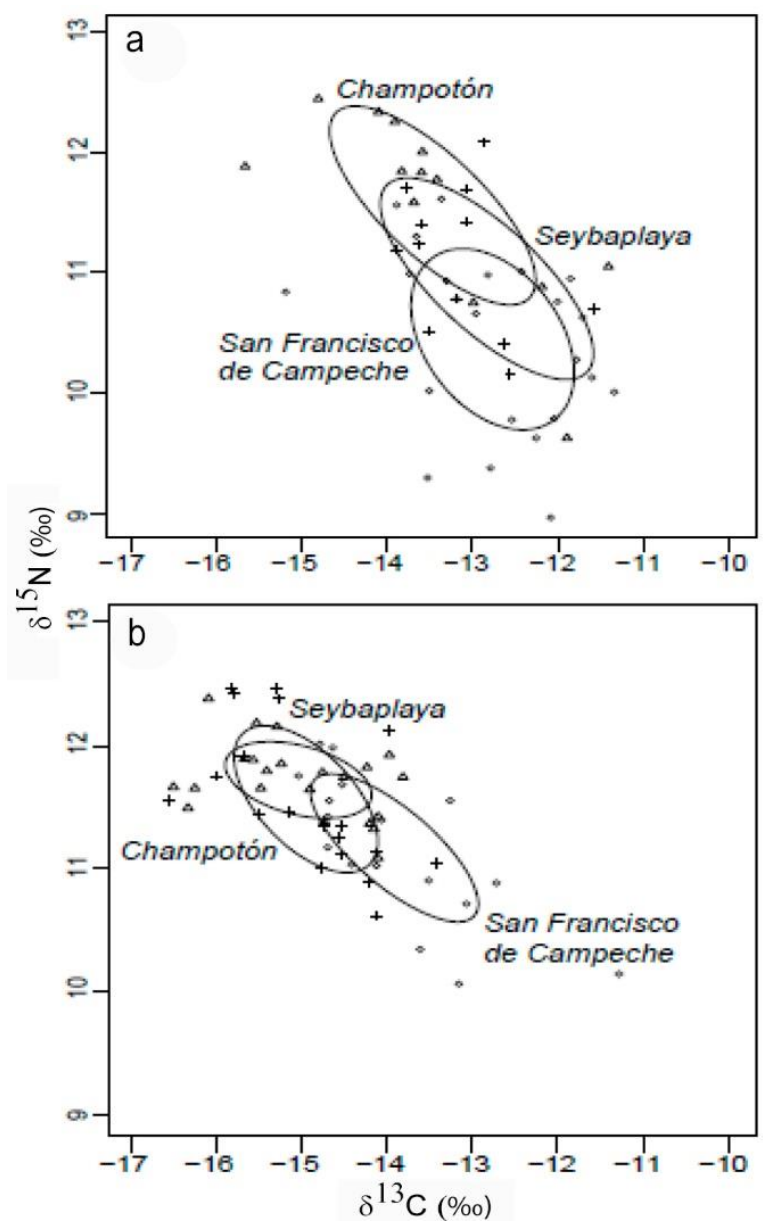

Figure 6. Standard ellipses for the muscle of a) Lutjanus griseus and b) L. synagris in the litoral of Campeche, Mexico. In both figures, triangles: Champotón, circles: San Francisco de Campeche and crosses: Seybaplaya.

trawling of the nearby rivers and with the presence of seagrass and mangroves. It has been confirmed that lutjanids are highly dependent on adjacent mangrove and seagrass ecosystems since they are breeding or feeding areas (Nagelkerken, 2007; Vaslet et al., 2012), therefore, L. synagris is ecologically fed in areas of seagrass and $L$. griseus is probably intermittent between seagrass and mangrove areas. Since both snapper species occupy different habitats of the food web in the Campeche coast, like other lutjanids species (Garrido et al., 2008; Vaslet et al., 2012), the absence of these species probably can cause a top-down effect on the ecosystem. The existence of top-down control, which means the regulation of lower food-web components by one or several upper-level predators, as species mostly interact through predation, should be critical in the functioning of marine ecosystems (Cury et al., 2003). Predation mortality is estimated to be a significant source of mortality for marine exploited species. An analysis of six marine ecosystems (Benguela 


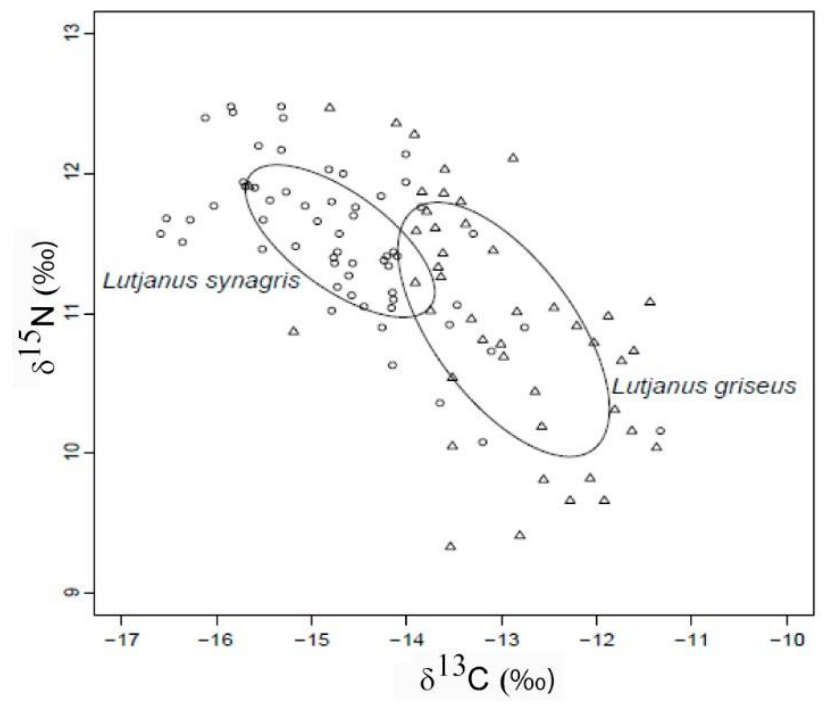

Figure 7. Biplot of $\delta^{13} \mathrm{C}$ and $\delta^{15} \mathrm{~N}$ for Lutjanus griseus and L. synagris in the littoral of Campeche, Mexico.

Current, Georges Bank, Balsfjord, east Bering Sea, North Sea, Barents Sea) suggests that predation represents between 2-35 times fishing mortality (Bax, 1991; Cury et al., 2003). The top-down is closely linked to keystone species as well as trophic cascade, and these processes have been well demonstrated in several aquatic ecosystems by Paine (1966), Power et al. (1996), Oleson (1995), Estes et al. (1998) and most recently by Schneider \& Brose (2012), Hall (2015) and Lynam et al. (2017).

The temporal trophic spectrum of L. griseus indicated that the diet was similar throughout the year. Several authors mention for Lutjanus genus not seasonal variations in the composition of the diet, for example, Lutjanus colorado, present no significant difference in food preferences during dry and rainfall season in the Gulf of Nicoya (Claro, 1981a,b, 1983a,b,c; Guevara et al., 1994, Sierra et al., 1994), and the difference in $\delta^{15} \mathrm{~N}$ among location can be related to change in the organic matter. The type of substrate being the determining factor of the sea, Rivera-Arriaga et al. (2012), indicated a transition zone between Champoton and San Francisco de Campeche with changes in sediments.

The location of San Francisco de Campeche presents slime-clays; while Seybaplaya and Champoton, sands (68.87\%) and with high density of seagrasses, also, the vast supply of nutrients from the Champoton River in wind/winter season (W), coupled with the efficient use by the ichthyofauna of the energy in the leaves of Thalassia testudinum. Therefore, ichthyofauna tends to present an isotopic composition of locally available organic matter (Poppe et al., 2000; Romo-Ríos, 2012), where although $L$. griseus feed very similarly at the spatial level, the isotopic difference $\left(\delta^{15} \mathrm{~N}\right)$ can be due to changes in the autotrophic source between localities.

In $L$. synagris, the significant difference at the spatial and temporal levels was found in stomach content and stable isotopes. In the winter/wind season, L. synagris consumed mainly shrimps (Penaeidae) and crabs (Callinectes spp.). In D season, swimming crabs and shrimps (Portunus spp. and Sycionidae), and $\mathrm{R}$ season crabs and swimming crabs (Majidae and Portunus spp.), coincident with Guevara et al. (1994) who reported for $\mathrm{R}$ season, that crustaceans represented the highest percentage of food consumed for three lutjanids species, since during this season there is an increase in primary productivity, increasing productivity in zooplankton and benthic organisms. However, the differences detected with stable isotopes suggested a differential pattern in the use of prey resources according to the temporality.

In Campeche throughout the year, crustaceans have a high abundance. However, there have been changes at the temporal/spatial level in this taxonomic group's abundances. For example, juveniles of the family Portunidae are usually found in the sediment in areas less than 20-30 m deep to spend the winter (months of northerly) (Williams et al., 1990), as well as the Penaeidae, have higher activity under very turbid conditions in the water column (Hughes, 1968), probably associated to changes in temperature or the influx of nutrients (especially in the rainy season) as well as other environmental factors. Therefore, in $\mathrm{N}$ season, $L$. synagris feed on benthos; whereas in dry and rainy seasons in the water column.

The trophic level of $L$. synagris and L. griseus (around 3.9) corresponds to that of tertiary consumers (Vander-Zanden et al., 1999). However, Sierra et al. (1994) have reported higher trophic levels for $L$. synagris and $L$. griseus (from 4.0 to 4.3 ). These differences can be attributed to the fact that the main prey in the diet of snappers in Cuba is mostly Osteichthyes (high TL). The trophic positions based on stable isotopes are slightly higher than trophic positions of lutjanids trophic in Florida, probably related to the type of habitat (Vaslet et al., 2012 - study = neritic areas). Therefore, the present study proves that lutjanids in their different distributions (mangroves, seagrass, neritic areas) have a unique and critical role in the dynamics of marine ecosystems as predators and potential structuring of their prey populations mainly of benthic organisms.

In summary, despite being sympatric species captured in the coastal area, with a preference for crustaceans, the isotopic composition allows us to detect that $L$. synagris and $L$. griseus occupy different 
Table 6. Values of $\delta^{15} \mathrm{~N}, \delta^{13} \mathrm{C}$, and C:N ratio of food sources (prey species) of lutjanids at the corresponding locations. n: number of individuals, SD: standard deviation.

\begin{tabular}{|c|c|c|c|c|c|}
\hline Location & Prey items & $\mathrm{n}$ & $\delta^{13} \mathrm{C}(\%) \pm \mathrm{SD}$ & $\delta^{15} \mathrm{~N}(\%) \pm \mathrm{SD}$ & $\mathrm{C}: \mathrm{N}$ \\
\hline \multicolumn{6}{|c|}{ San Francisco de Campeche } \\
\hline & Lagodon rhomboidalis & 2 & $-12.2 \pm 0.2$ & $9.0 \pm 0.2$ & 2.8 \\
\hline & Majidae & 4 & $-12.5 \pm 0.2$ & $3.9 \pm 0.3$ & 3.1 \\
\hline & Fultodromia spp. & 7 & $-12.3 \pm 1.5$ & $3.8 \pm 1.2$ & 2.7 \\
\hline & Epathus epheliticus & 1 & -11.2 & 6.7 & 3.2 \\
\hline & Ocyurus chysurus & 2 & $-11.8 \pm 0.7$ & $6.1 \pm 0.5$ & 4.2 \\
\hline & Farfantepenaeus aztecus & 2 & $-13.4 \pm 0.1$ & $5.3 \pm 1.0$ & 3.1 \\
\hline & Farfantepenaeus duorarum & 2 & $-12.5 \pm 0.1$ & $7.3 \pm 1.5$ & 3.2 \\
\hline \multicolumn{6}{|c|}{ Seybaplaya } \\
\hline & Portunus gibbesii & 6 & $-14.7 \pm 0.8$ & $7.4 \pm 0.9$ & 3.8 \\
\hline & Trachypenaeus constrisctus & 2 & $-15.5 \pm 0.4$ & $6.0 \pm 0.6$ & 3.3 \\
\hline & Farfantepenaeus duorarum & 2 & $-12.8 \pm 8.3$ & $6.4 \pm 8.2$ & 3.4 \\
\hline & Archosargus rhomboidalis & 2 & $-15.6 \pm 0.3$ & $8.0 \pm 0.5$ & 2.8 \\
\hline & Lutjanus synagris & 2 & $-13.1 \pm 1.0$ & $8.1 \pm 1.1$ & 2.3 \\
\hline & Menipe mercenaria & 1 & -10.4 & 5.8 & 4.0 \\
\hline & Partenophe pourtalessi & 3 & $-15.7 \pm 1.0$ & $6.0 \pm 1.2$ & 3.0 \\
\hline & Callinectes spinnimanus & 2 & $-16.4 \pm 0.9$ & $7.6 \pm 1.0$ & 4.0 \\
\hline \multicolumn{6}{|c|}{ Champoton } \\
\hline & Myrophis punctatus & 2 & $-11.8 \pm 0.2$ & $8.7 \pm 3.1$ & 2.9 \\
\hline & Portunus gibbesii & 2 & $-13.4 \pm 0.9$ & $6.1 \pm 0.4$ & 3.0 \\
\hline & Squilla empusa & 2 & $-15.3 \pm 0.3$ & $7.7 \pm 0.1$ & 3.5 \\
\hline & Farfantepenaeus duorarum & 2 & $-13.5 \pm 1.4$ & $5.9 \pm 1.5$ & 3.0 \\
\hline & Urobatus jamaicensis & 2 & $-12.4 \pm 0.1$ & $10.1 \pm 0.2$ & 3.2 \\
\hline & Callinectes sapidus & 3 & $-15.7 \pm 0.1$ & $6.0 \pm 0.4$ & 2.0 \\
\hline & Menipe mercenaria & 3 & $-12.2 \pm 0.7$ & $4.8 \pm 1.0$ & 3.6 \\
\hline & Fultodromia spp. & 7 & $-16.7 \pm 1.7$ & $5.0 \pm 1.6$ & 2.8 \\
\hline
\end{tabular}

trophic roles in different habitats like mangrove and seagrass areas, confirming that these areas are potential areas for the breeding and growth of snappers in the coastal zone of the Campeche. There are few studies based on stable isotope for the Gulf of Mexico's coastal area, and this study proves that the application of this technique is crucial to understand the biology and behavioral characteristics of snappers in other regions. However, future studies need to determine the importance of the coastal zone's organic sources for ichthyofauna and this through intensive analyzes in the determination of $\delta^{13} \mathrm{C}$ at different points of the coast, such as in seagrass, mangrove, coral areas, with the contribution of rivers or groundwater. All these aspects will allow us to contribute to the ecosystem management of one of the most valuable fisheries in the Gulf of Mexico.

\section{ACKNOWLEDGMENTS}

PGJC thanks to: Consejo Nacional de Ciencia y Tecnología (CONACyT) and Programa de Becas para Estudios de Posgrado for the scholarship granted with ID number 704997. EFMF and YETR thanks to:
Consejo Nacional de Ciencia y Tecnología (CONACyT) for the project: Ciencia Basica \#42984 and SEMARNAT-CONACyT \#263401, respectively. SAG thanks to: Secretaría de Investigación y Posgrado del IPN for the projects SIP20196704, SIP20201301.

\section{REFERENCES}

Amundsen, P.A., Gabler, H.M. \& Stalduick, F.J. 1996. A new approach to graphical analysis of feeding strategy from stomach contents data modification of the Costello (1990) method. Journal of Fish Biology, 48: 607-614.

Bax, N.J. 1991. A comparison of the fish biomass flow to fish, fisheries, and mammals on six marine ecosystems. ICES Journal of Marine Science, 193: 217-224.

Bearhop, S., Adams, C.E., Waldron, S., Fuller, R.A. \& Macleod, H. 2004. Determining trophic niche width: a novel approach using stable isotope analysis. Journal of Animal Ecology, 73: 1007-1012.

Bester, C. 2015. Gray snapper: ichthyology at the Florida Museum of Natural History. [http://www.flmnh.ufl. 
edu/fish/gallery/descript/graysnapper/graysnapper.ht ml]. Reviewed: September 20, 2019.

Brown, S.C., Bizzarro, J.J., Cailliet, G.M. \& Ebert, D.A. 2012. Breaking with tradition: redefining measures for diet description with a case study of the Aleutian skate Bathyraja aleutica (Gilbert 1896). Environmental Biology of Fishes, 95(1): 3-20.

Brulé, T., Colas, T., Pérez, E. \& Deniel, C. 2004. Biología y explotación de los meros. (Serranidae, Epinephelinae, Epinephelini) y pargos (Lutjanidae, Lutjaninae, Lutjanus) del Golfo de México. Diagnóstico ambiental de Golfo de México. Secretaría del Medio AmbienteInstituto de Ecología, Ciudad de México, pp. 245-285.

Christensen, V. \& Pauly, D. 1992. A guide to the ECOPATH II program (version 2.0). ICLARM software 6. International Center for Living Aquatic Resources Management, Manila, 71 pp.

Clarke, K.R. \& Warwick, R.M. 1994. Similarity-based testing for community pattern: the 2-way layout with no replication. Marine Biology, 118: 167-176.

Claro, R. 1981a. Ecología y ciclo de vida del pargo criollo, Lutjanus analis (Cuvier), en la plataforma cubana. Informe científico técnico. Biología pesquera. Academia de Ciencias de Cuba, 186: 1-83.

Claro, R. 1981b. Ecología y ciclo de vida de la biyajaiba Lutjanus synagris (Linnaeus) en la plataforma cubana. Informe científico técnico. Biología pesquera. Academia de Ciencias de Cuba, 177: 1-53.

Claro, R. 1983a. Ecología y ciclo de vida de la rabirubia Ocyurus chrysurus (Bloch) en la plataforma cubana. Identificación, distribución, hábitat, reproducción y alimentación. Informe científico técnico. Academia de Ciencias de Cuba, 15: 1-33.

Claro, R. 1983b. Ecología y ciclo de vida de la biajaiba, Lutjanus synagris, (Linnaeus), en la plataforma cubana. Dinámica estacional de algunos indicadores morfofisiológicos. Reporte de Investigación del Instituto de Oceanología, Academia de Ciencias de Cuba, 1: 1-24.

Claro, R. 1983c. Ecología y ciclo de vida del caballerote Lutjanus griseus (Linnaeus), en la plataforma cubana. Identidad, distribución y hábitat, alimentación y reproducción. Reporte de Investigación del Instituto de Oceanología, Academia de Ciencias de Cuba, 7: 1-30.

Colwell, R.K. 2006. EstimateS: statistical estimation of species richness and shared species from samples. [http://purl.oclc.org/estimates]. Reviewed: September 20, 2019.

Comisión Nacional de Acuacultura y Pesca (CONAPESCA). 2019. Estadísticas de producción pesquera, México. [https://www.conapesca.gob.mx/wb/cona/ estadisticas_de_produccion_pesquera]. Reviewed: September 20, 2019.
Cortés, E. 1999. Standardized diet compositions and trophic levels of sharks. ICES Journal of Marine Science, 56: 707-717.

Castro-Aguirre, J.L., Espinoza-Pérez, H. \& SchmitterSoto, J.J. 1999. Ictiofauna estuarino-lagunar y vicaria de México. Limusa-Noriega/IPN, Ciudad de México.

Cury, P., Shannon, L. \& Shin, Y.J. 2003. The functioning of marine ecosystems: a fisheries perspective. In: Sinclair, M. \& Valdimarsson, G. (Eds.). Responsible fisheries in the marine ecosystem. Centre for Agricultural Bioscience International, Wallingford, pp. 102-23.

De Ruiter, P.C., Wolters, V. \& Moore, J.C. 2005. Dynamic food webs. Multispecies assemblages, ecosystem development and environmental change. Theoretical ecology series. Academic Press, Cambridge, pp. 3-10.

Duarte, L.O. \& García, C.B. 1999. Diet of the mutton snapper Lutjanus analis (Cuvier) from the Gulf of Salamanca, Colombia, Caribbean Sea. Bulletin of Marine Science, 65: 453-465.

Estes, J.A., Tinker, M.T., Williams, T.M. \& Doak, D.F. 1998. Killer whale predation on sea otters linking oceanic and nearshore ecosystems. Science, 282: 473476.

Ferry, L.A. \& Cailliet, G.M. 1996. Sample size sufficiency and data analysis: are we characterizing and comparing diet properly. In: MacKinlay, D. \& Shearer, K. (Eds.). Feeding ecology and nutrition in fish. Proceedings of the Symposium on the Feeding Ecology and Nutrition in Fish. International Congress on the Biology of Fishes, San Francisco, pp. 71-80.

Fischer, W. 1978. FAO species identification sheets for fishery purposes. FAO, Roma.

Froese, R. \& Pauly, D. 2010. World wide web electronic publication. FishBase. [https://www.fishbase.de/]. Reviewed: September 10, 2019.

Galván-Magaña, F. 1988. Composición y análisis de la dieta del atún aleta amarilla Thunnus albacares en el Pacífico mexicano durante 1984-1985. Tesis de Maestría, CICIMAR-IPN, La Paz.

Garrido, A., Castillo, E. \& Félix, F. 2008. Preferencias alimenticias de las especies comerciales más importantes del género Lutjanus en el litoral costero del estado de Tabasco, México. Revista Kuxulkab, 15(27): 55-57.

Guevara, E., Álvarez, H., Mascaró, M., Rosas, C. \& Sánchez, A. 2007. Hábitos alimenticios y ecología trófica del pez Lutjanus griseus (Pisces: Lutjanidae) asociado a la vegetación sumergida en la Laguna de Términos, Campeche, México. Revista de Biología Tropical, 955(3-4): 989-1004. 
Guevara, E., Bosch, A., Suárez, R. \& Lalana, R. 1994. Alimentación natural de tres especies de pargos (Pisces: Lutjanidae) en el Archipiélago de los Canarreos, Cuba. Revista de Investigaciones Marinas, 15: 63-72.

Hall, A.E. 2015. Top-down control, trophic interactions, and the importance of predatory fishes on coral reefs. Ph.D. Thesis, James Cook University, Queensland.

Harrigan, P., Zieman, J.C. \& Macko, S.A. 1989. The base of nutritional support for the gray snapper (Lutjanus griseus): an evaluation based on a combined stomach content and stable isotope analysis. Bulletin of Marine Science, 44(1): 65-77.

Hettler, W.F. 1989. Food habits of juveniles of spotted sea trout and gray snapper in western Florida Bay. Bulletin of Marine Science, 44(1): 155-162.

Hoffman, M. 1979. The use of Pielou's method to determine sample size in food studies. In: Lipovsky, S.J. \& Simenstad, C.A. (Eds.). Gutshop 78': Fish food habits studies. Proceedings of the second Pacific Northwest Technical Workshop. Washington Sea Grant Publications, University of Washington, Seattle, pp. 56-61.

Hobson, K.A. 1999. Tracing origins and migration of wildlife using stable isotopes: a review. Oecologia, 120: 314-326.

Hughes, D.A. 1968. Factores que controlan aparición de camarón rosado (Penaeus duorarum) del sustrato. Biological Bulletin, 134(1): 48-59.

Jackson, J.B.C., Kirby, M.X., Berger, W.H., Bjorndal, K.A., Botsford, L.W., Bourque, B.J., et al. 2001. Historical overfishing and the recent collapse of coastal ecosystems. Science, 293: 629-638.

Juárez, D.E. 2011. Nivel trófico del pargo cálale, Lutjanus synagris (Linaeus, 1758) en la Bahía de Amatique, Puerto Barrios, Izabal, Guatemala. Tesis de Maestría, Universidad de San Carlos de Guatemala, Ciudad de Guatemala.

Kareiva, P.M. \& Levin, S.A. 2003. The importance of species: perspectives on expendability and triage. Princeton University Press, New Jersey, pp. 1-427.

Krebs, C.J. 1999. Ecological methodology. Addison Wesley Longman, Boston.

Labropoulou, M. \& Eleftheriou, A. 1997. The foraging ecology of two pairs of congeneric demersal fish species: importance of morphological characteristics in prey selection. Journal of Fisheries Biology, 50: 324-340.

Lagler, K.F., Bardach, J., Millar, R. \& May-Pasino, D. 1984. Ictiología. AGT Editor, Ciudad de México.

Lynam, C.P., Llope, M., Möllmann, C., Helaouët, P., Bayliss-Brown, G.A. \& Stenseth, N.C. 2017. Interaction between top-down and bottom-up control in marine food webs. Proceedings of the National Academy of Sciences, 114(8): 1952-1957.
Maruyama, A., Yamada, Y., Rusuwa, B. \& Yuma, M. 2001. Change in stable nitrogen isotope ratio in the muscle tissue of a migratory goby, Rhinogobius sp., in a natural setting. Canadian Journal of Fisheries and Aquatic Science, 58: 2125-2128.

Madigan, D., Carlisle, A. \& Dewar, H. 2012. Stable isotope analysis challenges wasp-waist food web assumptions in an upwelling pelagic ecosystem. Scientific Reports, 2: 654. doi: 10.1038/srep00654

McIntyre, P.B. \& Flecker, S.A. 2006. Rapid turnover of tissue nitrogen of primary consumers in tropical freshwaters. Oecologia, 148: 12-21.

Nagelkerken, I. \& Van Der Velde, G. 2004. Are Caribbean mangroves important feeding grounds for juvenile reef fish from adjacent seagrass beds? Marine Ecology Progress Series, 274: 143-151.

Nagelkerken, I. 2007. Are non-estuarine mangroves connected to coral reefs through fish migration? Bulletin of Marine Science, 80(3): 595-607.

Oksanen, J., Guillaume-Blanchet, F., Kindt, R., Legendre, P., Minchin, P.R., O'Hara, R.B., Simpson, G.L., Solymos, P., Henry, M., Stevens, H. \& Warner, H. 2015. vegan: Community Ecology Package. R Package version 2.2.1. [http://CRAN.R-project.org/ package=vegan]. Reviewed: September 20, 2019.

Oleson, N.J. 1995. Clearance potential of jellyfish Aurelia aurita, and predation impact on zooplankton in a shallow cove. Marine Ecology Progress Series, 124(13): 63-72.

Paine, R.T. 1966. Food web complexity and species diversity. American Naturalist, 1000: 65-75.

Park, R. \& Epstein, S. 1961. Metabolic fractionation of ${ }^{13} \mathrm{C}$ and ${ }^{12} \mathrm{C}$ in plants. Plant Physiology, 36: 133-138.

Pérez-Farfante, I. \& Kensley, B. 1997. Penaeoid and Sergestoid shrimps and prawns of the world. Keys and diagnoses for the families and genera. Mémoires du Muséum National d'Histoire Naturelle, 175: 233 pp.

Phillips, D.L. \& Gregg, J.W. 2003. Source partitioning using stable isotopes: coping with too many sources. Oecologia, 136: 261-269.

Pimm, S.L. 2002. Food webs. Chapman and Hall, London.

Pimentel, C.R. \& Joyeux, J.C. 2010. Diet and food partitioning between juveniles of mutton Lutjanus analis, dog Lutjanus jocu and lane Lutjanus synagris snappers (Perciformes: Lutjanidae) in a mangrovefringed estuarine environment. Journal of Fish Biology, 76: 2299-2317.

Poppe, J.L., Knebel, H.J., Mlodzinska, Z.J., Hastings, M.E. \& Seekins, B.A. 2000. Distribution of surficial sediment in Long Island Sound and adjacent waters: texture and total organic carbon. Journal of Coastal Research, 16(3): 567-574. 
Post, D.M. 2002. Using stable isotopes to estimate trophic position models, methods, and assumptions. Ecology, 83(3): 703-718.

Post, D.M., Layman, C.A., Takimoto, G., Quattrochi, J. \& Montaña, C.G. 2007. Getting to the fat of the matter: models, methods and assumptions for dealing with lipids in stable isotope analyses. Oecologia, 152: 179189.

Power, M.E., Tilman, D., Estes, J.A., Menge, B.A., Bond, W.A., Mills, L.S., Daily, G., Castilla, J.C., Lubchenco, J. \& Paine, R.T. 1996. Challenges in the quest for keystones. Bioscience, 46(8): 609-620.

R Core Team. 2014. R: a language and environment for statistical computing. R Foundation for Statistical Computing. [http://www.R-project.org]. Reviewed: June 12, 2019.

Reséndez, M.A.1981a. Estudio de los peces de la Laguna de Términos, Campeche, México. I. Biótica, 6: 239291.

Reséndez, M.A. 1981b. Estudio de los peces de la Laguna de Términos, Campeche, México. II. Biótica, 6: 345430.

Rivera-Arriaga, E., Lara-Domínguez, A.L., RamosMiranda, J., Sánchez-Gil, P. \& Yáñez-Arancibia, A. 1993. Ecology and population dynamics of Lutjanus synagris on Campeche Bank. Proceedings of the International Workshop on Tropical Snappers and Groupers, Part II. Biology, ecology and distribution. EPOMEX-ICLARM, Campeche, pp. 11-18.

Rivera-Arriaga, E., Alpuche, G.M., Negrete, C.J., Nava, F., Lemus, P. \& Arriaga, Z. 2012. Programa de manejo costero integrado para el saneamiento de la Bahía de San Francisco de Campeche. Universidad Autónoma de Campeche, Campeche, 68 pp.

Rojas-Herrera, A.A., Mascara, M. \& Chiappa-Carrara, X. 2004. Hábitos alimentarios del huachinango (Lutjanus peru) y del flamenco (Lutjanus guttatus) (Pisces: Lutjanidae) en la costa de Guerrero, México. Revista de Biología Tropical, 52: 959-971.

Romo-Ríos, A. 2013. Productores primarios y su relación con la distribución de la ictiofauna en Laguna de Términos y plataforma continental adyacente, Campeche, México. Tesis de Maestría, CICIMARIPN, La Paz, 100 pp.

Rooker, J.R. 1995. Feeding ecology of the schoolmaster snapper, Lutjanus apodus (Walbaum), from southwestern Puerto Rico. Bulletin of Marine Science, 56: 886-899.

Rooker, J.R., Turner, J.P. \& Holt, S.A. 2006. Trophic ecology of Sargassum-associated fishes in the Gulf of Mexico determined from stable isotopes and fatty acids. Marine Ecology Progress Series, 313: 249-259.

Sámano-Zapata, J.C., Vega-Cendejas, M.E. \& Hernández, M. 1998. Alimentary ecology and trophic interaction of juveniles "pargo mulato" (L. griseus Linaeus. 1758) and "rubia" (L. synagris Linaeus, 1758) from the noroccidental coast of the Yucatán Peninsula, México. Proceedings of the Gulf and Caribbean Fisheries Institute, 50: 804-826.

Santamaría-Miranda, A., Elorduy-Garay, I.F. \& RojasHerrera, A.A. 2003. Hábitos alimentarios de Lutjanus peru (Pisces: Lutjanidae) en las costas de Guerrero, México. Revista de Biología Tropical, 51: 503-517.

Saucedo-Lozano, M. 2000. Alimentación natural de juveniles de Lutjanus peru (Nichols y Murphy, 1922) y Lutjanus guttatus (Steindachner, 1869) (Lutjanidae: Perciformes) en la costa de Jalisco y Colima, México. Ciencias Marinas, 25(3): 381-400.

Sierra, L.M. 1996. Relaciones tróficas de los juveniles de cinco especies de pargo (Pisces: Lutjanidae) en Cuba. Revista de Biología Tropical, 44(3)/45(1): 499-506.

Sierra, L.M., Claro, R. \& Popova, O.A. 1994. Alimentación y relaciones tróficas. In: Claro, R. (Ed.). Ecología de los peces marinos de Cuba. Instituto de Oceanología, Academia de Ciencias de Cuba y Centro de Investigaciones de Quintana Roo, Quintana Roo, pp. 263-284.

Sinervo, B. 1997. Optimal foraging theory: constraints and cognitive processes. University of California, Santa Cruz, pp. 105-130.

Stillwell, C.E. \& Kohler, N.E. 1982. Food, feeding habits, and estimates of daily ration of the shortfin mako (Isurus oxyrinchus) in the northwest Atlantic. Canadian Journal of Fisheries and Aquatic Science, 39(3): 407-414.

Schoener, T.W. 1974. Resource partitioning in ecological communities. Science, 185: 27-39.

Schneider, F.D., Scheu, S. \& Brose, U. 2012. Body mass constraints on feeding rates determine the consequences of predator loss. Ecology Letters, 15: 436443.

Steel, R.G.D. \& Torrie, J.H. 1992. Bioestadística. Principios y procedimientos. Editorial Graf América, Ciudad de México.

Stephens, D.W. \& Krebs, J.R. 1986. Foraging theory. Princeton University Press, New Jersey.

Vaslet, A, Phillips, D.L., France, C., Feller, I.C. \& Baldwin C.C. 2012. The relative importance of mangroves and seagrass beds as feeding areas for resident and transient fishes among different mangrove habitats in Florida and Belize: evidence from dietary and stable-isotope analyses. Experimental Marine Biology and Ecology, 434-435: 81-93.

Vander-Zanden, M.J., Lester, N.P., Shuter, B.J. \& Rasmussen, J.B. 1999. Patterns of food chain length in lakes: a stable isotope study. American Naturalist, 154: 406-416. 
Werner, P.A. 1979. Competition and coexistence of similar species. In: Solbrig, O.T., Jain, S., Johnson, G.B. \& Raven, P.H. (Eds.). Topics in plant population biology. Columbia University Press, New York, pp. 287-312.

Williams, H.A., Coen, L.D. \& Stoelting, M. 1990. Seasonal abundance, distribution, and habitat selection of juvenile Callinectes sapidus (Rathbunae) in the northern Gulf of Mexico. Journal of Experimental Marine Biology and Ecology, 137(3): 165-183.

Received: November 4, 2019; Accepted: March 10, 2020
Yáñez-Arancibia, A. \& Day, J.W. 1982. Ecological characterization of Terminos Lagoon, a tropical lagoon-estuarine system in the southern Gulf of Mexico. Oceanológica Acta, 5(4): 431-440.

Yáñez-Arancibia, A. \& Day Jr. J.W. 1986. Ecología de la zona costera: análisis de siete trópicos. ACT Editor, Ciudad de México. 